\title{
Hydrogeological compartmentalization and connection of the Guarani (GAS) and Serra Geral (SGAS) aquifer systems from a multiscale perspective: a case study in southern Brazil
}

\author{
Rafaela Chirst da Silva ${ }^{1}$ (D), Francisco Manoel Wohnrath Tognoli ${ }^{* *}$ (D), Pedro Antonio Roehe Reginato ${ }^{2}$ (1), \\ Paulo Salvadoretti ${ }^{3}$ (D), Laís Vieira de Souza' ${ }^{1}$ (D)
}

\begin{abstract}
The Guarani (GAS) and Serra Geral (SGAS) aquifer systems are the main groundwater sources in southern Brazil. We investigated the crucial relationship between the primary, intergranular pore system in the GAS and the secondary pore system associated with fractures in the SGAS in order to understand better the compartmentalization and connection, water storage, and productivity of both aquifers. Data from 375 wells that produce from both aquifers was used to evaluate the hydrodynamic characteristics of the GAS-SGAS contact. The integration of data using remote sensing, structural data, and thin section analysis support interpretations about the compartmentalization and potential connection of the aquifers. Fault zones trending NW, EW, and NNE demarcate six structural blocks in which the GAS-SGAS contact varies more than $400 \mathrm{~m}$ in elevation. Thin section analysis of sandstone texture and composition allowed us to determine the relationship between the type of porosity and cement type and content. The surface demarcating the Guarani-Serra Geral contact is highly productive in $93 \%$ of the wells that reach both aquifers. The integration of our results allowed us to propose a conceptual hydrogeological model for the GAS and SGAS aquifers in the study area.
\end{abstract}

KEYWORDS: groundwater flow; granular-fractured connection; lineaments; structural compartmentalization; Paraná Basin.

\section{INTRODUCTION}

Granular and fractured aquifer systems constitute most of the groundwater sources available for human, industrial, and agricultural activities throughout the world. Although granular aquifers have been used and studied for many decades, fractured aquifers have only been addressed in research in the last years and their understanding presents many challenges. Fractured aquifers have heterogeneous and anisotropic hydraulic properties (Lindholm and Vaccaro 1988, Reginato et al. 2013), and groundwater storage and flow are controlled by fractures (Dafny et al.2006), as well as by porous media such as amygdaloidal vesicle zones (Uhl Jr.

\footnotetext{
${ }^{1}$ VizGEO Sci Data Lab, Programa de Pós-Graduação em Geologia, Universidade do Vale do Rio dos Sinos - São Leopoldo (RS), Brazil. E-mail: rafaela.christ@hotmail.com, ftognoli@unisinos.br

${ }^{2}$ Programa de Pós-Graduação em Recursos Hídricos e Saneamento Ambiental, Instituto de Pesquisas Hidráulicas, Universidade Federal do Rio Grande do Sul - Porto Alegre (RS), Brazil. E-mail: pedro. reginato@ufrgs.br

${ }^{3}$ Programa de Pós-Graduação em Engenharia de Minas, Metalúrgica e de Materiais, Escola de Engenharia, Universidade Federal do Rio Grande do Sul - Porto Alegre (RS), Brazil. E-mail: paulo.salvadoretti@ufrgs.br, vsouzalais@gmail.com

${ }^{*}$ Corresponding author.
}

and Joshi 1986). Granular and fractured aquifers can occur in contact with each other, and hydraulic characteristics derived from their connection and compartmentalization are not well-known.

This context is particularly crucial for hydrogeological research, as the Continental Flood Basaltic provinces (CFB) represent the most extensive magmatic flows recorded in geological history (Jerram and Widdowson 2005, Waichel et al. 2012). They are recorded in the Deccan Plateau in India (Kulkarni et al.2000, Katpatal et al. 2014), Paraná-Etendeka in South America and South Africa (Erlank et al. 1984, Peate et al. 1990), Rio Columbia Plateau in the USA (Whiteman et al. 1994), Golan Heights in Israel (Dafny et al. 2006), and Dalha Basalts in Djibouti, Africa (Jalludin and Razack 1994). These geological settings are likely to develop aquifers in their domains because fracturing in lava flow units naturally develops through time by cooling and tectonic processes. Large aeolian deposits are older than basalts, but they can also be coeval with those rocks bearing fractures, locally juxtaposing the basalts (Almeida and Melo 1981, Scherer 2000, 2002).

The study area is located near the Serra Geral Plateau, part of the Paraná-Etendeka Province in southern Brazil. It includes two aquifer systems: Guarani (GAS) and Serra Geral (SGAS) (Fig. 1), which provide groundwater to more than 9 million people, agriculture, and industries in Brazil, Paraguay, Uruguay, and Argentina (Gastmans et al. 2016). Geologically, they 

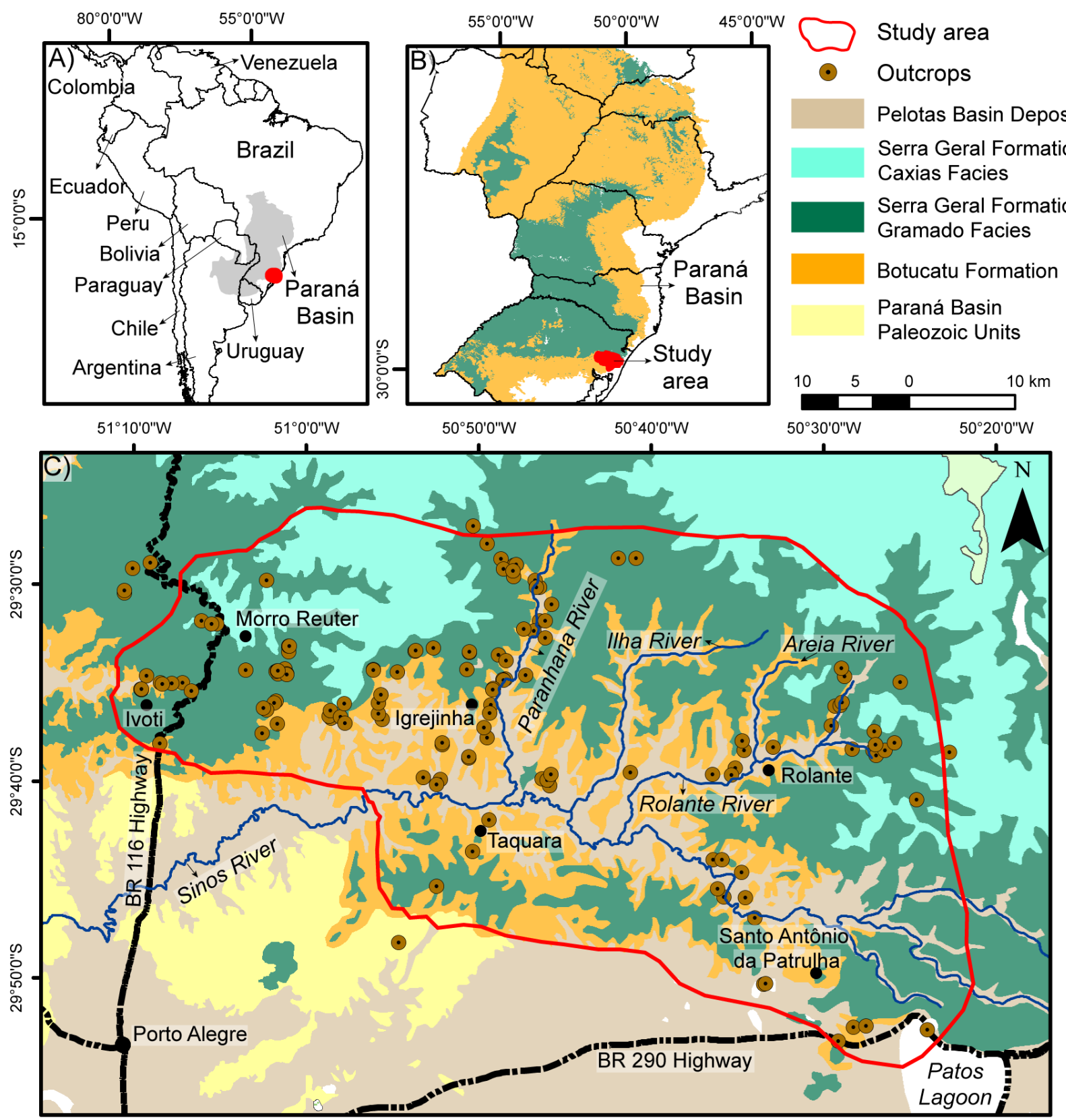

Source: modified from CPRM (2008).

Figure 1. Location map of the study area. See the geographical location in (A) and the geological context in (B). A more detailed view in (C) displays the limits of the area, the main outcrops, and the lithostratigraphic units over the geological map.

represent a continental succession formed by one to six hundred meters of thick sandstones of the Botucatu Formation, a large aeolian dune field deposit developed in the center-south of South America during the Jurassic-Cretaceous periods (Scherer 2000, Milani et al. 2007). It is overlain by 100 to 1,700-m thick succession of basaltic to rhyodacite magma flows recorded as the Serra Geral Formation (Schneider et al. 1974, Milani et al. 2007), developed as a response to the Gondwana breakup during the Lower Cretaceous (Turner et al. 1994, Renne et al. 1996). The Botucatu Formation is the central unit of the granular GAS, whereas the Serra Geral Formation encompasses the fractured SGAS. The contact between the two aquifers is not well-known from a hydrogeological point of view, especially in terms of storage, flow, and physical connection between them (Uhl Jr. and Joshi 1986, Fernandes et al. 2012, 2016, Gastmans et al. 2017).
The GAS has a classical primary intergranular porosity developed by depositional and diagenetic processes, whereas the SGAS has secondary fracture porosity generated during magma cooling and tectonic processes as well as porosity associated with amygdaloidal vesicles developed in the upper portion of magma flows by degasification (Domenico and Schwartz 1990, Jalludin and Razack 1994, Machado 2005, Machado and Freitas 2005). These types of porosity control the behavior of each aquifer, but other factors should also be considered such as the influence of tectonics on the development of structures and fracture connections, geomorphologic patterns, and lithological characteristics at different scales. Thus, the main objective of this study is to evaluate how tectonic, structural, lithological, and diagenetic characteristics act to affect the flow path of groundwater and the productivity of these aquifers (GAS and SGAS). 


\section{THE GEOLOGY OF THE PARANÁ- ETENDEKA PROVINCE AND RELATED AQUIFER SYSTEMS}

\section{General aspects}

The Paraná-Etendeka Province records volcanic processes that occurred during the Lower Cretaceous and released a volume of basic-to-acidic magma of up to $1 \times 10^{6} \mathrm{~km}^{3}$ (Erlank et al. 1984, Peate et al. 1990, Turner et al. 1994, Renne et al. 1996, Jerram et al. 2000, Jerram and Widdowson 2005). Covering an area up to $1 \times 10^{6} \mathrm{~km}^{2}$ and with a thickness ranging from 300 to more than $1,500 \mathrm{~m}$, these rocks represent the product of a Large Igneous Province (LIP) developed between 135 and 130 M.a. (Turner et al. 1994, Renne et al. 1996). This magma flooding spread over erg-type desertic environments fed by deep fractures into the crust as a result of the tectonic processes involved in the breakup of Gondwana. The release and spreading of magma to the surface had as a primary control the position of crustal weakness zones, the regional dip, the relief associated with the dune fields, and the position of the water bodies (Jerram and Widdowson 2005). This association records a succession characterized by aeolian well-sorted, fine-grained quartzous sandstones named as the Botucatu Formation in Brazil (Schneider et al. 1974, Scherer 2000) and Etjo Formation, Huab Basin, in Namibia (Jerram et al. 1999) overlain by the basic-to-acidic lava flow deposits (locally with interbedded sandstones) of the Serra Geral Formation in Brazil (White 1908, Schneider et al. 1974) and the Awahab Formation in Africa (Jerram et al. 2000). During the first magmatic events, basaltic lavas had direct contact with the underlying sands, and the lava-sediment interaction preserved many geomorphologic features of the paleo-desert (Mountney et al. 1999, Jerram et al. 2000, Scherer 2002).

The extensive sandy deposits reported as the Botucatu Formation are a widespread lithostratigraphic unit in the Paraná Basin, distributed over $840,000 \mathrm{~km}^{2}$ in Paraguay, Uruguay, and center and south of Brazil (Scherer 2000). It is the most representative unit of the GAS, constituted by tens of meters of cross-stratified Jurassic aeolian sandstones, characterized by well-sorted, high sphericity, subrounded to well-rounded, very fine-to-medium grains of quartzous to arkosic composition with siliceous, carbonate, and ferruginous cement and primary intergranular porosity. The Botucatu Formation can reach up to $600 \mathrm{~m}$ in maximum thickness (Milani 1997, Milani et al.2007), but the thickness is quite variable due to erosion caused by tectonic uplifts at some portions and the preservation of the dune morphology at others, in which they can reach 1,000 m (Araújo et al. 1995, 1999, Machado 2005, Machado and Freitas 2005). These two aspects control the position of the Botucatu-Serra Geral contact at different altitudes, even in the same study area, allowing the GAS and SGAS aquifers to be laterally in contact.

The volcanic rocks of the Serra Geral Formation overlying the aeolian deposits throughout Paraná basin (White 1908, Schneider et al. 1974) have a composition that ranges from ultrabasic (Lomba Grande Facies), basic (Gramado Facies), to acidic (Caxias Facies) (CPRM 2008), from the base to the top. In the study area, basalts and rhyodacites predominate in the volcanic succession, which also has some loose sandstone intercalations, as a product of the aeolian-erg processes developed after each lava flow that were not lithified because of rapid burial by other lava flows (Petry et al. 2005, Reis et al. 2014).

\section{Compartmentalization and connection of the GAS and SGAS}

Fractures developed from the tectonic events resulted from the stress propagated along the entire succession in rocks with different rheological characteristics. Thus, fault zones promote the compartmentalization of the aquifers, and fracture sets can propagate along juxtaposed aquifers connecting them (Fernandes et al. 2012, 2016) and increasing the groundwater productivity (Uhl Jr. and Joshi 1986). In these cases, connected aquifers show water compositions resulting from the mixture of waters enriched by elements derived from minerals and weathering products of each geological context (Deutsch et al. 1982, Gastmans et al. 2016).

Lava flows and cooling on the surface resulted in volumetric contraction with decreased temperature and the development of vertical fractures that could connect one another, generating the hexagonal pattern known as columnar jointing. Degasification is another feature resulting from magma decompression that promotes the accumulation of gas bubbles at the top of each lava flow deposit. The combination of fractures and vesicular zones constitutes the primary conduits for groundwater flow in basaltic aquifers such as those of the SGAS (Deutsch et al. 1982). It creates a complex porous system formed by vesicles and amygdales limited by subhorizontal surfaces that border the top of the lava flow. Vesicle-dominated zones have a high permeability when the voids are connected, but they can be almost impermeable if infilled with secondary minerals (Naik et al. 2001). If there is water inside the vesicles, fractures can horizontally and vertically connect the water stored in different vesicular zones (Kulkarni et al. 1997, Johnson et al. 2002).

The succession formed by several lava flows has developed sets of fractures to respond to the tectonic events that affected the deposits after cooling. The connection of fractures of different orientations tends to increase permeability, and faults can connect different fracture sets, significantly increasing permeability (Rebouças and Fraga 1988, Jalludin and Razack 1994). In specific cases, faults may act as a permeability barrier due to the presence of fine-grained material produced by rock crushing in the fault core. The damage zone, on the contrary, is often characterized by a well-connected fracture system that is more permeable than the fault core.

The compartmentalization of the GAS and SGAS is controlled and influenced at the basin scale by Precambrian fault zones in the basement of Paraná Basin, which were reactivated throughout the Phanerozoic (Fulfaro et al. 1982, Araújo et al. $1995,1999)$. More specifically, in southern Brazil, Machado (2005) recognized four main blocks in the GAS limited by NE-SW and NW-SE lineaments. On a more local scale of analysis, the aquifer shows specific characteristics that must be considered for compartmentalization analysis such as diagenetic aspects that turn sandstones hard enough to be fractured. Compartmentalization controls are key to understand 
the extreme variability in aquifer productivity such as its flow rate ranging from 0.5 to about $66 \mathrm{~m}^{3} / \mathrm{h}$, and a specific capacity ranging from near zero to about $11.5 \mathrm{~m}^{3} / \mathrm{h} / \mathrm{m}$ in the study area. The nature of the compartmentalization is a function of the thickness variation in the lithostratigraphic units by geomorphological paleosurfaces or structural highs, fault zones, and erosion at the borders of the basin (Soares 2008).

The relationship between the GAS and SGAS has the thickness and type of fractures of the Serra Geral Formation as the primary control of the confinement and recharge of the GAS (Wahnfried 2010). From studies in southeastern Brazil at the municipality of Ribeirão Preto, Fernandes et al. (2012) inferred that vesicular basalts at the top of lava flows acted as regional hydraulic barriers because the cooling processes did not permit the fracture propagation beyond each lava flow, preventing it from reaching the underlying sandstones of the GAS. The main patterns of fractures trend NNE, NW, and ENE in the region of Ribeirão Preto, and NNE, WNW, and $\mathrm{NE}$ in the region of São Paulo (Fernandes et al. 2016). In the study area at the Rio Grande do Sul, south Brazil, Matos et al. (2018) identified structural lineaments with NS, EW, NW, and subordinately NE orientations, corroborating the lineament patterns identified by Heine (2008) in the sediment-lava thermal metamorphism contact between GAS and SGAS. However, there is no strong evidence of fractures (joints) connecting and supplying water from the SGAS to the GAS in southern Brazil. Therefore, understanding the connection between GAS and SGAS remains a challenge, and more data acquisition and field observations are needed. Fault systems and lineaments have been previously recognized as possible connection elements (Freitas 2016, Tomasi and Roisenberg 2019, Matos 2020). From a hydrogeochemistry point of view, Reginato et al. (2013) pointed out that the aquifer connection was indicated by hydrochemical analysis due to the hydraulic head differences, reflecting in sodium bicarbonate, sodium chloride, or sulfate-enriched compositions in which the GAS was confined. Matos (2020), then, identified upward recharge from (pre-) GAS to SGAS near the study area.

The mixture of waters from the GAS and SGAS evidenced by their hydrochemical and isotopic compositions also indicates that the groundwater flow is associated with the principal rivers of the area, along with valleys that cut the basalts and the sandstones, influenced by the relief (Gastmans and Chang 2012, Gastmans et al. 2016). These flow paths modify the groundwater composition between the recharge and discharge areas. The feldspar and calcite contents of sandstones of the GAS were removed by dissolution along tens of kilometers downdip in the basin by the influence of meteoric water. This process opened the pore system and modified the water composition by increasing the content in ions, such as $\mathrm{K}^{+}, \mathrm{Ca}^{+2}, \mathrm{Al}^{+3}$, and $\mathrm{SiO}_{2}(\mathrm{aq})$, in which the aquifer is confined, as presented and discussed by França et al. (2003) and Gastmans et al. (2010). The aforementioned authors pointed out that these ions also created cemented zones within the aquifer, obliterating porosity (e.g., calcite, chalcedony, quartz overgrowths) or generating associated microporosity (e.g., kaolinite, smectite). The greater the thickness of the volcanic rocks, the less evident the weathering affecting sandstones of the GAS, decreasing feldspar dissolution, silica release, and the amount of cement, thereby facilitating groundwater flow.

\section{MATERIAL AND METHODS}

This study had three main analyses performed and integrated, involving petrology, structural analysis (fractures and lineaments), and hydrogeology. The Shuttle Radar Topography Mission (SRTM) provided the regional structural trends from images with a 30-m spatial resolution. Using shaded relief maps in scales of 1:750,000, 1:400,000, 1:250,000, and 1:100,000, structural lineaments were visually identified and demarcated in the ArcMap ${ }^{\circledR} 10.3$ version to calculate their orientation and length. The analysis and integration of geological data and elevation of the Botucatu-Serra Geral contact allowed the demarcation of six structural blocks, named A-F.

The petrological aspects of the volcanic and sedimentary rocks analyzed from mapping along natural outcrops, quarries, and roadcuts included descriptions and measurements in outcrops, hand samples, and thin sections. The fieldwork allowed mapping the Botucatu and Serra Geral units and marking the altimetric position of their contact, demarcating the base and top of lava flows and their vesicular zones, acquiring structural data, and collecting samples for detailed petrographic analysis. Measuring the fractures using a compass demonstrated the local structural patterns of both the Botucatu and Serra Geral formations. The field measurements of the strikes were plotted in rose diagrams and stereograms to compare the orientations of geological structures in different scales. Dip angles were high (higher than $70^{\circ}$ ) in most of the measured fractures, while all the vertical fractures were exclusively related to columnar jointing. Fracture density was divided into four classes, null (0 fracture/meter), low ( $<2$ fractures/meter), medium $(2 \leq$ fractures/meter $\leq 5$ ), high ( $>5$ fractures/meter). Structural measurements collected inside one well from $360^{\circ}$ images acquired by an Optical Televiewer (OTV) allowed the fracturing pattern in both units and measure planar structures as fractures and bedding surfaces to be analyzed using the WellCAD ${ }^{\circledR}$ software.

Sixteen thin sections of sandstones from the six different structural blocks were made by impregnation of blue epoxy resin to enhance porosity. Textural and compositional aspects involving grains, matrix, cement, and porosity were analyzed with a Zeiss Axio Lab optical microscope using a scientific camera mounted into an acquisition system of $12 \mathrm{MPx}$ and operated with the Zen ${ }^{\circledR}$ software. Descriptions included grain size variation, sorting, roundness, sphericity, types of porosity, and grain and cement composition. The classification of sandstones followed the proposition of Folk (1974). The quantification by modal counting of 300 points per thin section allowed the comparison and identification of different characteristics of each block inside the study area. The relationship between detrital composition, type of cement, and porosity were demonstrated through quantification using microscopic analysis and assisted in evaluating permeability barriers down to the microscale.

The hydrogeological characterization used the well inventory data from the Brazilian Groundwater Information System 
(SIAGAS) of the Geological Survey of Brazil (CPRM), from the Companhia Riograndense de Saneamento (Sanitation Company of the State of Rio Grande do Sul - CORSAN), from the Department of Housing and Sanitation (SEHABS), and database from private institutions. A total of 600 wells were analyzed, and 375 of them were selected for data compilation. Three groups of wells were selected based on depth of water inlet as follows: 99 wells with water inlet from the SGAS, 175 from the GAS, and 101 from both SGAS and GAS. The primary data were the elevation of the water table and the hydrodynamic parameters of flow rate and specific capacity used in maps drawn in the ArcMap 10.3 software interpolated with inverse distance weighting (IDW). Elevation of the BotucatuSerra Geral interface and the altimetric position of water inlet in both aquifers were determined using mean and median supported data to represent two geological sections drawn in Adobe Illustrator ${ }^{\oplus} 2018$. These geological sections crossed the study area in a zigzag pattern to represent all the six blocks in the study area, divided in intervals with different orientations.

The integration of all collected data was fundamental to propose geological sections and a conceptual framework of the hydrogeological compartmentalization, aquifer connection, and groundwater flow in the study area.

\section{RESULTS}

\section{Regional structural trends}

A total of 35 lineaments identified on a 1:750,000 scale presented orientations trending NS, WNW (N80-90W), ENE
(N80-90E), NW (N30-45W), and NE (N40-55E), whereas 1,340 lineaments on a scale of 1:250,000 presented orientations trending NNW (NS-N10W), NNE (NS-N20E), ENE (N80E-EW), and ENW (N80W-EW) (Fig. 2). The 35 lineaments identified on a 1:750,000 scale included a set of 8 lineaments of more than $15 \mathrm{~km}$ in length, which were easily recognized as geomorphological features, and coincident with the valleys of the most important rivers (e.g., Sinos, Paranhana, Rolante, Ilha, and Areia rivers - see Fig. 1) that limit six structural blocks in the study area (Fig. 2).

\section{Aquifer system characterization}

A total of 99 wells produce water from the SGAS and permitted the identification of groundwater flow to the southeast and subordinately to the east (Fig. 3). The recharge zone is in the North of the study area, while the discharge zone is along the Sinos River, running parallel to the main tectonic lineament. Seven wells have flow rates higher than $30 \mathrm{~m}^{3} / \mathrm{h}$ in the Northwestern and Southeastern areas, including the higher flow rate of the study area: $66 \mathrm{~m}^{3} / \mathrm{h}$ in Morro Reuter municipality. The lowest flow rates are in the Center-South region, and their specific capacity ranges from 0.1 to $1 \mathrm{~m}^{3} / \mathrm{m} / \mathrm{h}$, but values higher than $2 \mathrm{~m}^{3} / \mathrm{m} / \mathrm{h}$ have been recorded in 14 wells in the Northwest and Southeast of the area. More detailed productivity data about the SGAS are available in Table 1.

Processing of data from 175 wells with a water inlet in the GAS demonstrated the main groundwater flow occurring toward the southeast, along the Sinos River, but there was also flow to the north towards the Paranhana River, associated with structural lineaments presented in Figure 3.

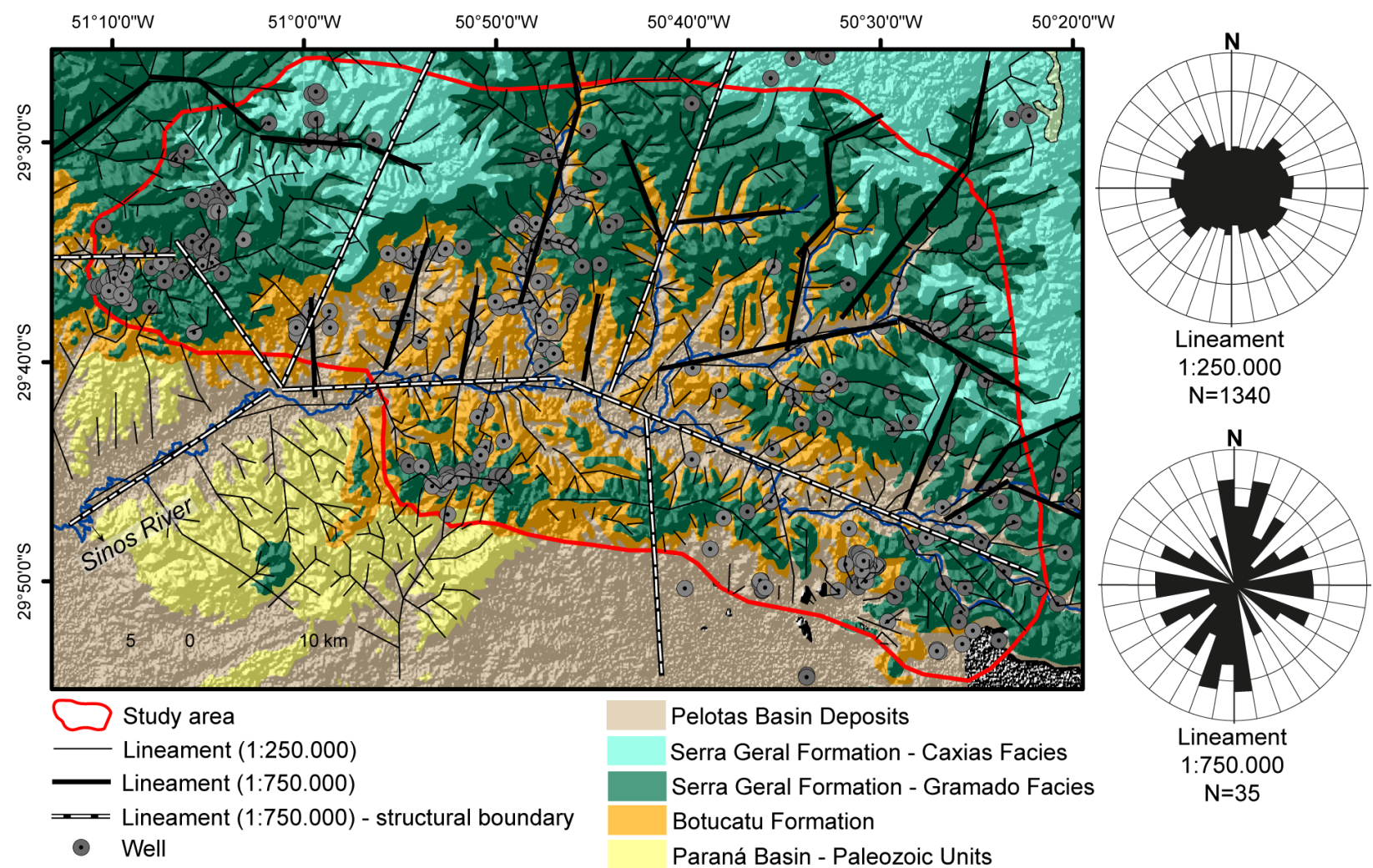

Figure 2. Geological map showing the 35 major lineaments identified from the satellite images on a 1:750,000 scale and the 1,340 lineaments demarcated on a 1:250,000 scale. Eight of these major structures demarcate the six structural blocks identified in the study area. Rose diagrams show the high dispersion of orientation of the entire dataset. 
a)
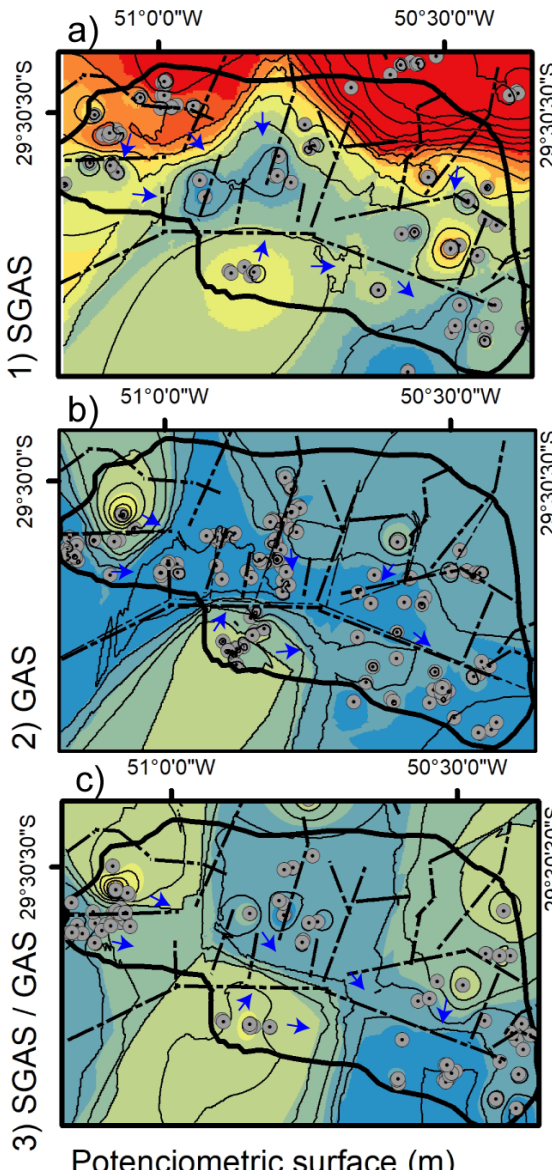

Potenciometric surface $(\mathrm{m})$

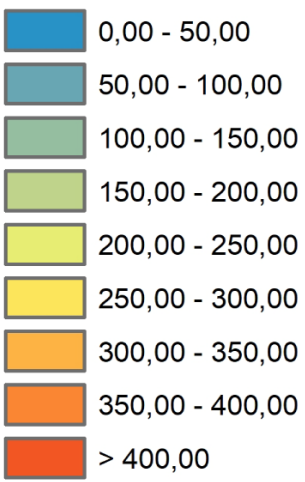

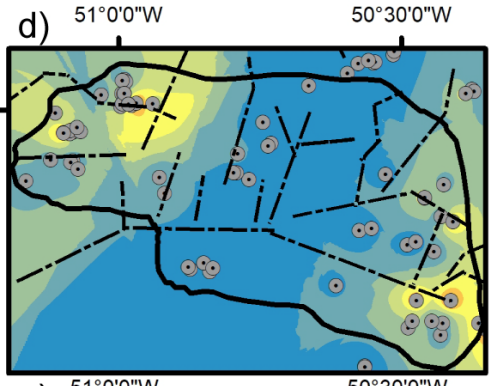
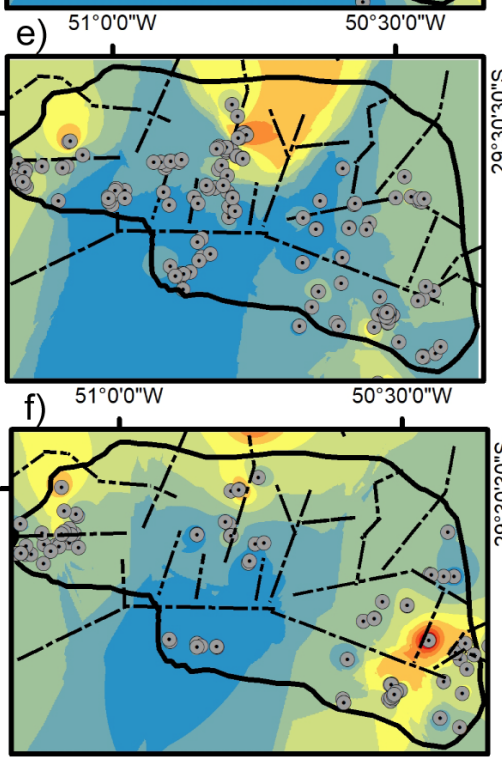

Flow rate $\left(\mathrm{m}^{3} / \mathrm{h}\right)$

$0,00-5,00$

$5,00-10,00$

$10,00-15,00$

$15,00-20,00$

$20,00-25,00$

$25,00-30,00$

$30,00-35,00$

$35,00-40,00$

$>40,00$
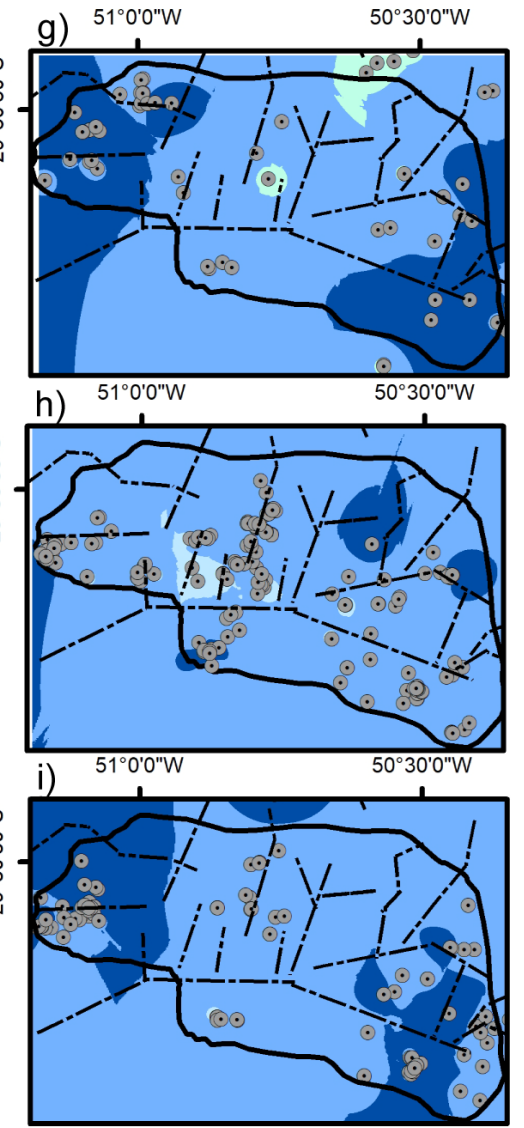

Specific capacity $\left(\mathrm{m}^{3} / \mathrm{h} / \mathrm{m}\right)$

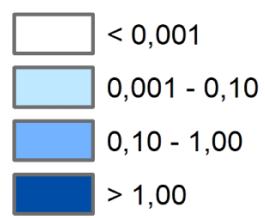

(1)
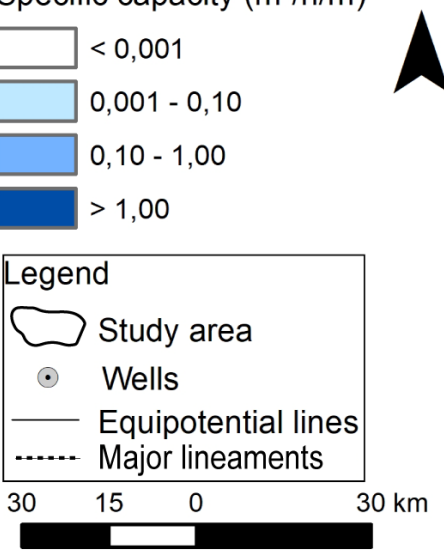

Figure 3. (A-C) Potentiometric, (D-F) flow rate, and (G-I) specific capacity maps of the wells producing from the SGAS, GAS, and SGAS+GAS. (A-C) Note the preferential groundwater flows indicated by blue arrows in the potentiometric maps of the (A) SGAS, (B) GAS, and (C) SGAS+GAS. In (C), compartments are evidenced by the light green color in the Northwest, Northeast, and Center-South of the area. (D-F) Flow rate maps evidencing high values in the North and Southeast and low values in the Center-South, coincident with the compartment suggested in (C). The highest flow rate in (F) occurs associated with the discharge zone. (G-I) Specific capacity maps indicating more productive potential in the Northwestern and Southeast areas.

The recharge zones were in the Northwest and Center-south, whereas the discharge zone was in the Southeast. Ten wells had flow rates higher than $30 \mathrm{~m}^{3} / \mathrm{h}$ in the Northwest, Southeast, and Center-South areas, including the highest flow rate of the area, $44 \mathrm{~m}^{3} / \mathrm{h}$ in the Igrejinha municipality. The lowest flow rates were in the Center-South of the area, and specific capacities ranged from 0.1 to $1 \mathrm{~m}^{3} / \mathrm{h} / \mathrm{m}$, but values of about $2 \mathrm{~m}^{3} / \mathrm{h} / \mathrm{m}$ were recorded in 8 wells in the Center-South, Northeast, and Northwest regions of the area. The maximum value of the flow rate was $5.3 \mathrm{~m}^{3} / \mathrm{h} / \mathrm{m}$ in the
Northwest. More detailed productivity data about the GAS is available in Table 1.

The data analysis of 101 wells with water inlets from the fractured SGAS and granular GAS showed their main groundwater flow to occur toward the Sinos River. A total of $93 \%$ of the wells had a water inlet in the surface that represented the contact of the Botucatu Formation and Serra Geral Formation. Ten wells, located in the Northwest and Center-North of the area, had a flow rate higher than $30 \mathrm{~m}^{3} / \mathrm{h}$. Flow rates higher than $50 \mathrm{~m}^{3} / \mathrm{h}$ occurred in the Southeast, with the highest value being 
$61 \mathrm{~m}^{3} / \mathrm{h}$. The lowest flow rates occurred in the Center-South of the area and were lower than $10 \mathrm{~m}^{3} / \mathrm{h}$. Specific capacities ranged from 0.1 to $1 \mathrm{~m}^{3} / \mathrm{m} / \mathrm{h}$, but values of about $2 \mathrm{~m}^{3} / \mathrm{m} / \mathrm{h}$ were recorded in 13 wells in the Northwest and Southeast. More detailed productivity data about the GAS/SGAS are available in Figure 3 and Table 1.

\section{Hydrogeological compartmentalization}

\section{Sandstone-basalt lithological contact}

The identification of structural lineaments on different scales, in geomorphological patterns, and respective to the position of the main rivers in the study area suggested hydrogeological compartments. The comparison of the altimetric position of an undoubtful geological contact (Botucatu-Serra Geral formations, or GAS-SGAS contact) ranged about $400 \mathrm{~m}$ in elevation, from a minimum of $-156 \mathrm{~m}$ in the Southeast to the maximum $+238 \mathrm{~m}$ in the Northwest (Tab. 2). These elevation values were used to demarcate six structural blocks (A-F), as shown in Figure 4. This variation was directly related to each structural block previously mentioned, as they reflect the relative vertical movements among them.

\section{Hydrodynamic characterization}

The hydrodynamic data about the flow rate and specific capacity of all productive wells from both GAS and SGAS aquifers (Tab. 3) shows that block $F$ was the most productive

Table 1. Statistical parameters of flow rate and specific capacity in wells with water inlet in the GAS, SGAS, and GAS+SGAS.

\begin{tabular}{lccc}
\hline & SASG & SAG & SASG+SAG \\
\hline Number of wells & 99 & 175 & 101 \\
\hline Flow rate $\left(\mathbf{m}^{3} / \mathbf{h}\right)$ & & & \\
\hline Minimum & 0.5 & 0.5 & 0.5 \\
Maximum & 66 & 44.03 & 60.92 \\
Mean & 10.6 & 10.71 & 14.42 \\
Median & 5.7 & 7.2 & 11.87 \\
Standard Deviation & 8.63 & 7.32 & 9.14 \\
\hline Specific capacity $\left(\mathbf{m}^{3} / \mathbf{m} / \mathbf{h}\right)$ & & \\
\hline Minimum & 0.0082 & 0.0079 & 0.0054 \\
Maximum & 11.6402 & 5.3080 & 0.9975 \\
Mean & 1.2636 & 0.4414 & 0.4614 \\
Median & 0.3663 & 0.2086 & 0.2963 \\
Standard Deviation & 1.3715 & 0.3989 & 1.217 \\
\hline
\end{tabular}

because it was coincident with the discharge zone of both GAS and SGAS, with a maximum flow rate of $61 \mathrm{~m}^{3} / \mathrm{h}$ and a maximum specific capacity of $7.2 \mathrm{~m}^{3} / \mathrm{m} / \mathrm{h}$. Block A was the second most productive, with a maximum flow rate of $46 \mathrm{~m}^{3} / \mathrm{h}$ and specific capacity of $10 \mathrm{~m}^{3} / \mathrm{m} / \mathrm{h}$.

With mean and median values of flow rate and specific capacity close to block A, block E, in the Northwest of the area, did not record high values for flow rate $\left(>15 \mathrm{~m}^{3} / \mathrm{h}\right)$ or high specific capacity $\left(>1 \mathrm{~m}^{3} / \mathrm{m} / \mathrm{h}\right)$, which determined its intermediate productivity. Block $\mathrm{C}$ had its productivity classified as intermediate in the Center-North of the area compared with other blocks, taking into account the high flow rate and specific conductivity evaluated from the borehole dataset. Block D, in the Center-South, represents the lowest productivity of the aquifer, with a flow rate of less than $10 \mathrm{~m}^{3} / \mathrm{h}$ and a maximum specific capacity of $0.25 \mathrm{~m}^{3} / \mathrm{m} / \mathrm{h}$. In the Northwest, block B had a high productivity, but a few wells crossed the BotucatuSerra Geral contact because it is the highest in altitude, where thick lava flows of volcanic rocks predominates and SGAS is the only or the more productive aquifer in that block.

\section{Structural trends in sandstones and basalts from surface and subsurface data}

The field measurement of planar surfaces taken from the Botucatu Formation sandstones and the Serra Geral volcanic rocks in the six structural blocks allowed the orientation patterns of their fractures to be defined (Fig. 5). The comparison of rose diagrams for all blocks indicated main orientations along ENE (N70E-EW), NNW (NS-N20W), and WNW (N70W-EW) directions for the basalts (Fig. 5A). For the sandstones (Fig. 5B), the main orientations are WNW (N70W-EW), ENE (N70E-EW), NE (N40-60E), and NW (N40-50W). Stereograms show the spatial orientation of the fractures present in the sandstones and basalts (Fig. 5C).

Most studied blocks present a fracturing pattern that reflects in at least one of the fracture sets regionally observed. Block A exhibits a preferential trend along ENE, WNW, and NE directions for both aquifers, but in GAS the fracture set running along the $\mathrm{NE}(\mathrm{N} 30-50 \mathrm{E})$ is the most obvious one (Fig. 5). Fractures of this block have different orientation patterns when compared with the regional trends along the NW (N30-40W), NNW (N10-20W), and ENE (N70E-EW). Block B presents more data dispersion in the fracture sets, but the typical pattern for both aquifers trends toward the NW. The NNW trend is expressive for the SGAS but not for the GAS. Fractures of this block have orientations along the NNE

Table 2. Statistical parameters of the altimetric position (meters) of the Botucatu-Serra Geral contact for each block.

\begin{tabular}{lcccccc}
\hline Block & A & B & C & D & E & F \\
\hline Minimum & -27 & 47 & -4 & -33 & -68 & -156 \\
Maximum & 135 & 238 & 206 & 224 & 210 & 79 \\
Mean & 67 & 128 & 61 & 157 & 81.55 & -10 \\
Median & 65 & 125 & 48 & 167 & 80.5 & 2 \\
Standard Deviation & 31.65 & 39.85 & 39.5 & 41 & 39.2 & 51 \\
\hline
\end{tabular}




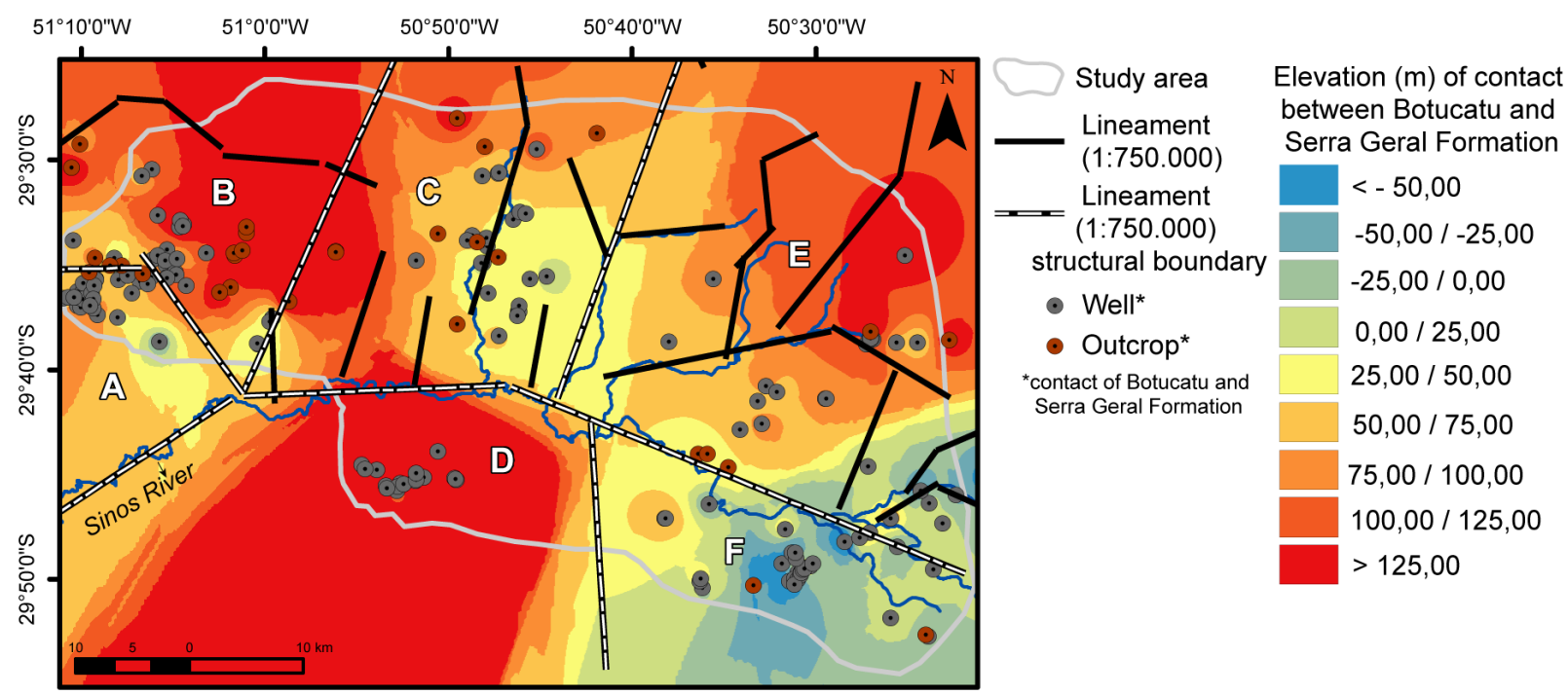

Figure 4. Elevation map of the contact between sandstones of the GAS and basalts of the SGAS evidencing the presence of structural blocks A to F.

Table 3. Statistical parameters of flow rate and specific capacity in wells with water inlet both in the GAS and SGAS.

\begin{tabular}{lcccccc}
\hline Block & A & B & C & D & E & F \\
\hline Number of wells & 25 & 5 & 18 & 10 & 11 & 30 \\
\hline Flow Rate $\left(\mathbf{m}^{3} / \mathbf{h}\right)$ & & & & & & \\
\hline Minimum & 4.06 & 4.55 & 1 & 1.8 & 1 & 0.5 \\
Maximum & 46.58 & 33 & 44 & 10.18 & 20.51 & 60.92 \\
Mean & 14.01 & 17.16 & 9.62 & 3.85 & 10.9 & 21.21 \\
Median & 12 & 15.54 & 6.75 & 2.09 & 12 & 17.22 \\
Standard Deviation & 6.56 & 12.57 & 7.26 & 2.56 & 4.42 & 10.72 \\
\hline Specific capacity $\left(\mathbf{m}^{3} / \mathbf{m} / \mathbf{h}\right)$ & & & & & & 0.053 \\
\hline Minimum & 0.0841 & 0.0746 & 0.046 & 0.017 & 0.0117 & 7.21 \\
Maximum & 10 & 11.6105 & 1.14 & 0.25 & 2.85 & 1.0982 \\
Mean & 1.2289 & 3.0179 & 0.54 & 0.1342 & 0.7574 & 0.3769 \\
Median & 0.356 & 0.1933 & 0.22 & 0.1511 & 0.4225 & 1.0261 \\
Standard Deviation & 1.302 & 4.2963 & 0.1862 & 0.064 & 0.7015 & \\
\hline
\end{tabular}

(N10-20E), ENE (N70E-EW), WNW (N70W-EW), and NW (N40-50W) (Fig. 5).

Blocks $\mathrm{C}$ and $\mathrm{D}$ do not show a direct relationship between the fracture sets of GAS and SGAS. The fractures of the sandstones in $\mathrm{C}$ have a well-defined orientation to the WNW. In block D, there are fewer structural data for the GAS because sandstones are not as fractured as in other blocks. The SGAS also had a limited structural sampling because basalts are quite rare in this block. The main orientation patterns for GAS and SGAS in block D are NE (N30-50E), WNW (N70W-EW), and NE (N50-70E), respectively. Fractures in block C are oriented to the NW (N40-50E) and NNE (N10-20E), and in the block D, to NW (N30-40W), WNW (N80W-EW), and NNW (NS-N20W). Block E has the ENE structures present in both aquifers, with the GAS presenting N70E-EW and N40-60W primary orientations, while the SGAS presents NE and NW patterns of approximately N50-70E and N10-20W. The main fractures are ENE (N70E-EW), WNW (N80W-EW), and
NNW (N10-30W). Block F has a strong relationship with ENE (N60-80E) and N30W fractures for the GAS and SGAS. However, sandstone has a WNW fracture set not observed in the basalts; the main fractures in the F block run along WNW (N60-70W) and NW (N10-30W) directions.

A subsurface sampling of structural data was obtained from the optical logging of one well (Cantagalo, Fig. 6), located at UTM coordinates $(544136 \mathrm{E}, 6716724 \mathrm{~N}, 232 \mathrm{~m}$, zone 22J, datum WGS 84), Block E, Rolante municipality (Fig. 1). The measurement of fractures along the whole well demonstrated two orientation trends in both aquifers to the EW and, subordinately, the NE. Sandstones of the GAS had orientation trends to NE (N40-50E) and WNW (N80W-EW); and basalts of the SGAS present fractures with orientation trends to NW (N20-30W), NE (N50-60E), and WNW (N80W-EW). Figure 6 shows three zones of interest identified along the well. Rose diagrams show the WNW (N70W-EW) trend as the main fracture set associated with minor local variations 


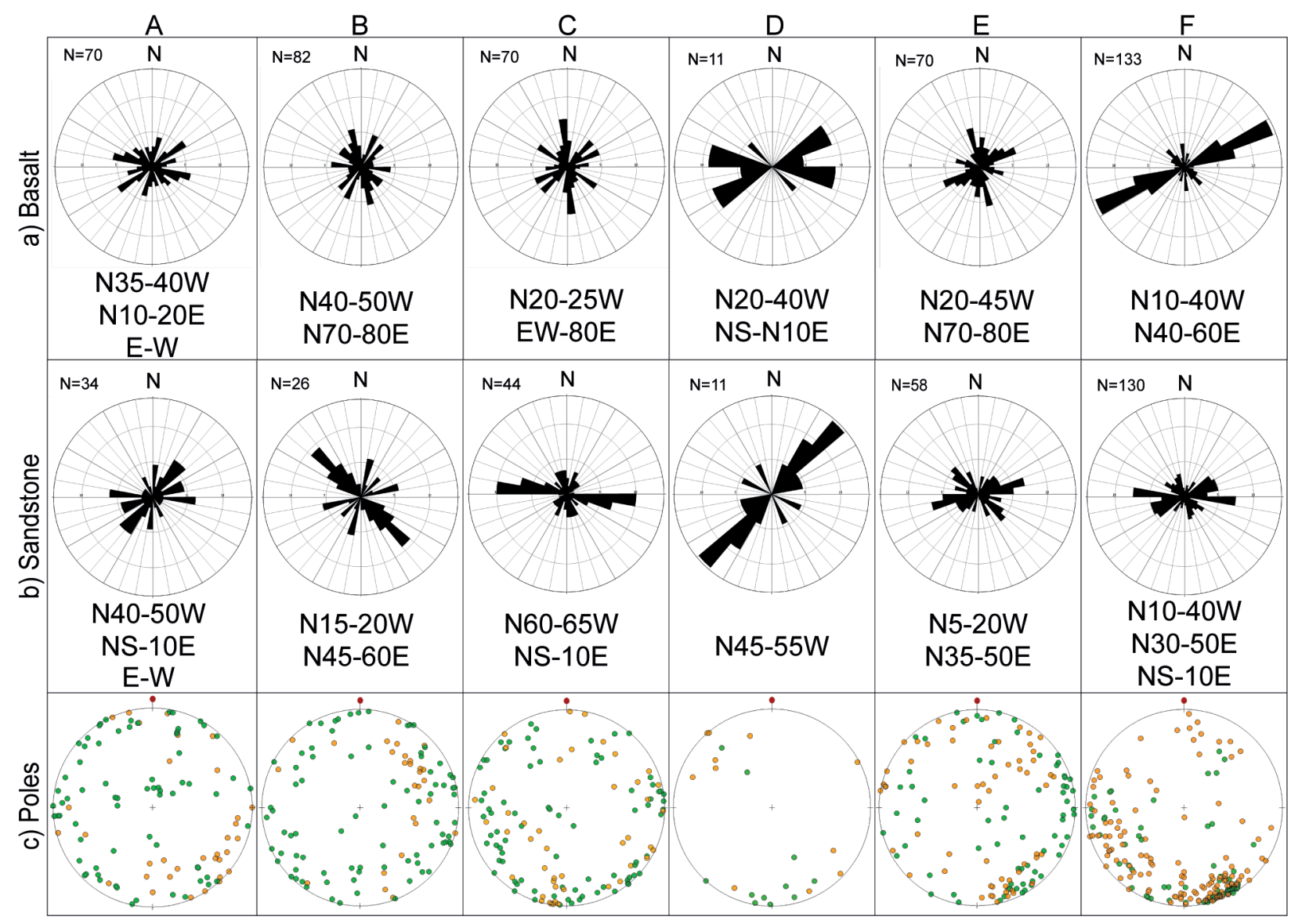

Figure 5. Rose diagrams and stereograms showing the orientation of fractures for each structural block for GAS and SGAS. Note the orientations WNW, ENE, and NE in different blocks and in both aquifers. Stereograms show similar orientations of fractures present in the GAS (orange) and SGAS (green).

in NE (N60-80E). In the zone of the Botucatu-Serra Geral contact, there are fractures with a prominent trend along the NNE (NS-N10E).

\section{Description of the structural blocks}

The mapping of the study area (Fig. 1) provided the geological characteristics of each structural block in terms of rock composition and structural pattern of the lava flow zones. The authors also observed different values of fracture density in both sandstones and basalts in all six structural blocks (Tab. 4).

Block A showed basalts with prominent columnar jointing, as well sandstones with large, metric-to-decametric cross-stratifications, and water inlets associated with cross-sets or diagenetic features such as tafoni. In block $\mathrm{B}$, there were a few outcrops of sandstones, but in some of them, the contact of sandstone intercalation within lava flows ("intertrappe sandstone") was observed. Sandstone is usually water-saturated and associated with reddish vesicular zones derived from the weathering of basalts displaying fractures with NW and NE orientations, whereas some sandstones exhibit intense fracturing. In the North of this block, at higher altitudes, more acidic volcanic rocks, such as the light-colored tabular rhyodacites of the Caxias Facies, crop out.

Block C, in the Center-North of the area, shows basalts with active weathering features associated with the vesicular zones shown in Figure 7A. The horizontal fractures (1) and subvertical ones trending NW and NNW (2) are very prominent in the basaltic rocks of this region. Fractures occurring in cross-stratified sandstones have the same orientation patterns to the NE and WNW as in the basalts, but their expression is different in each rock (Figs. 7B and 7C). A high fracturing density expressed as columnar jointing and one expressive NNW fault crossing the entire lava flow succession are shown in Figure 7D. Block D, in the Center-South, has only one exposed outcrop, which exhibits very few fractures and high contents of kaolinite as cement. Figures 7E and 7F show a very friable sandstone quarry with levels of kaolinite expressed by whitish to yellowish colors, with the presence of some fractures filled with clay material and oriented to the northeast (N65E and $\mathrm{N} 30 \mathrm{~W}$ ). Figure $7 \mathrm{G}$ illustrates a sandstone with a whitish color caused by a high kaolinitic cement content.

Block $\mathrm{E}$ is located in the Northeast of the study area, and the fracture sets run along the NNE, NE, and NW directions. During the fieldwork, water percolation along a fracture running to the NE (N30E) and NW (N60W) was observed (Fig. 8A). Two sandstone layers were also seen interbedded within basalt units. Sandstones are prone to have water inlet, as demonstrated by humid and water-saturated zones (Fig. 8B), where local fractures have orientations to the ENE and NW. In block F, fracture sets occur near the contact between sandstone and lava flow basalts with columnar jointing (Fig. 8C), whereas sandstones occur near basalts with well-developed 


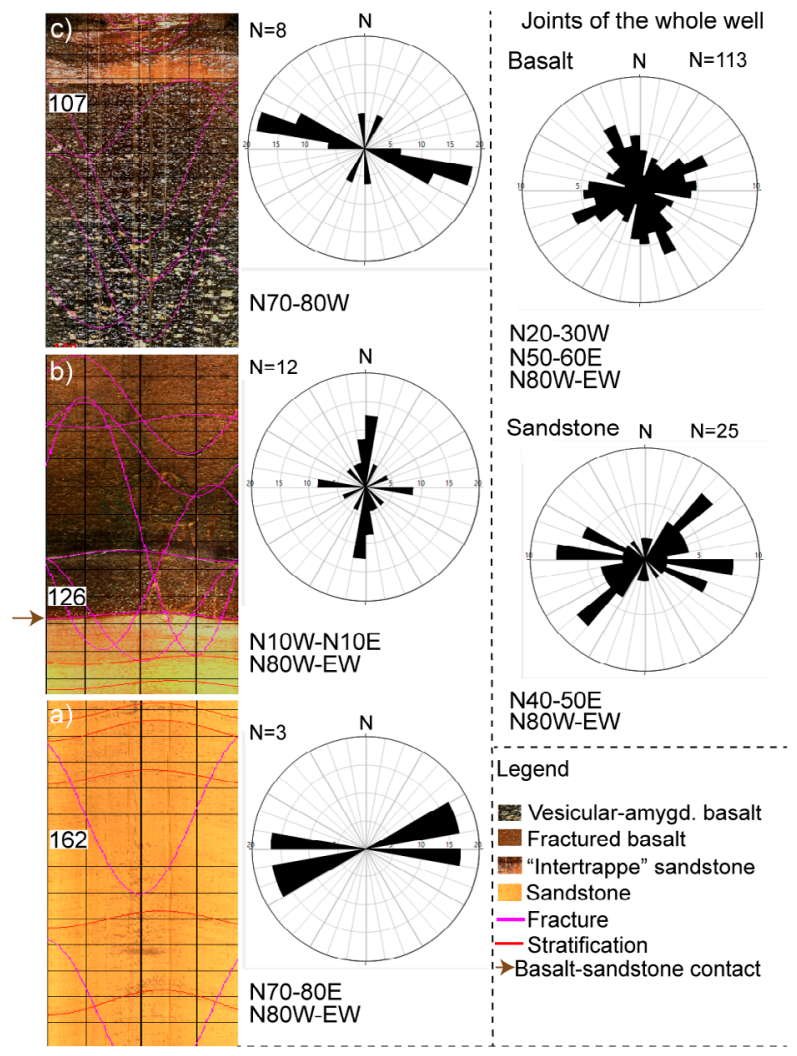

Figure 6. Optical images of the Cantagalo well and structural data. (A) Bedding surfaces (red line) and fractures (pink line) in the sandstones of the GAS. (B) Fractures in the GAS-SGAS contact. (C) Vesicular-amygdaloidal basalts with fractures and a sandstone bed intercalation. In the rose diagrams, note that the NW, NE, and ENE patterns are evident for the whole well. Near the contact of Botucatu-Serra Geral, a NS trend is prominent. The horizontal black lines in the pictures (A, B, and C) are 1-m thick.

Table 4. Fracture density in basalts and sandstones in each structural block.

\begin{tabular}{|c|c|c|c|}
\hline \multirow[b]{2}{*}{ Block } & \multirow{2}{*}{$\begin{array}{c}\text { Basaltic rock } \\
\text { predominant zone }\end{array}$} & \multicolumn{2}{|c|}{ Fracture density ${ }^{*}$} \\
\hline & & $\begin{array}{c}\text { Basaltic } \\
\text { rocks }\end{array}$ & Sandstones \\
\hline A & $\begin{array}{l}\text { Vesicular and } \\
\text { amygdaloidal, } \\
\text { horizontal and vertical } \\
\text { zones }\end{array}$ & High & Medium \\
\hline B & $\begin{array}{l}\text { Horizontal and } \\
\text { vertical zones }\end{array}$ & High & $\begin{array}{l}\text { Medium** } \\
\quad \text { (few } \\
\text { outcrops) }\end{array}$ \\
\hline $\mathrm{C}$ & $\begin{array}{l}\text { Vesicular and } \\
\text { amygdaloidal }\end{array}$ & Medium & High \\
\hline $\mathrm{D}$ & Null & Low or null & Low or null \\
\hline $\mathrm{E}$ & $\begin{array}{l}\text { Vesicular and } \\
\text { amygdaloidal, } \\
\text { horizontal and vertical } \\
\text { zones }\end{array}$ & High & Medium \\
\hline $\mathrm{F}$ & $\begin{array}{l}\text { Vesicular and } \\
\text { amygdaloidal, } \\
\text { horizontal and vertical } \\
\text { zones }\end{array}$ & High & High \\
\hline
\end{tabular}

${ }^{*}$ Fracture density based on: low $(<2$ fractures/meter), medium $(2 \leq$ fractures/meter $\leq 5)$, high $\left(>5\right.$ fractures/meter); ${ }^{* *}$ few outcrops available for measurements. fractures (Fig. 8D). Sandstones and basalts have fracture trends to the WNW and NW, and to the ENE, respectively. The contact between sandstones and a very weathered vesicular basalt crops out along the BR-290 roadcut (Fig. 8E) and exhibits fractures oriented between the ENE and WNW. Water percolation and humid zones in the rocks, with fractures oriented to the WNW, ENE, and NNW, were observed in this region.

\section{Petrography of sandstones}

The microscopic characterization of sandstones provided the textural and compositional characteristics of use to understand the relationship between porosity and cementation in samples collected in different structural blocks, as shown in Figure 9 and Table 5.

In block A, sandstones are quartzous, and samples were collected to represent different situations, e.g., as the thermal metamorphism close to the sandstone-basalt contact and friable samples with apparent high porosity where large pores in fractures created potential conduits for active water circulation (Fig. 9A). The samples from block B are sandstones interbedded in basalts (Fig. 8D) and characterized as an arkose with pore connections limited by cement among the grains (Fig. 9B). Block $\mathrm{C}$ presented arkoses with granulometric intercalations interpreted as a product of grain flow and grain fall processes. Porosity ranged between 2\% (Fig. 9C) and 13.3\% (Fig. 9D) as a function of the fracturing and iron oxide cement distributed in the pore system.

Three samples of sandstones analyzed in thin sections showed a quartzous composition in block $\mathrm{D}$. The lowest porosity in these sandstones was 3\%, with evident granulometric intercalations associated with grain fall and grain flow processes, but with conspicuous cementation by iron oxides and hydroxides (Fig. 9E). The most porous samples had $11.8 \%$ of intergranular porosity, but they also presented kaolinite distributed in the intergranular pores, which confined and restricted water percolation. Kaolinite as cement was observed to reduce porosity to values as low as $1.3 \%$ by filling almost all the intergranular pores (Figs. 9E and 9F).

The thin sections of the analyzed samples of block E, collected in the outcrop shown in Figure 8B, showed a subarkosean composition, with well-rounded grains, interstitial space not filled with cement, and porosity of $12.5 \%$ that derived from well sorting (Fig. 9G). Three thin sections from block F collected below, near, and above the sandstone-basalt contact had compositions classified between arkose and subarkose, and a variable density of fracturing showing a very low porosity of $1.3 \%$ in sandstones (Figs. 9G and 9H). Very close to the sandstone-basalt contact, the porosity was $17 \%$, and the pores were well-connected by microfractures (Fig. 9I), whereas sandstones, intercalated within the basalt lava flows with evident fracture sets (Fig. 8C), had a 14\% porosity (Fig. 9J).

\section{DISCUSSION}

Within a regional context, the main lineaments represent fault systems with preferential orientations in the NNW, NNE, $\mathrm{ENE}$, and EW directions derived from the reactivation of ancient 

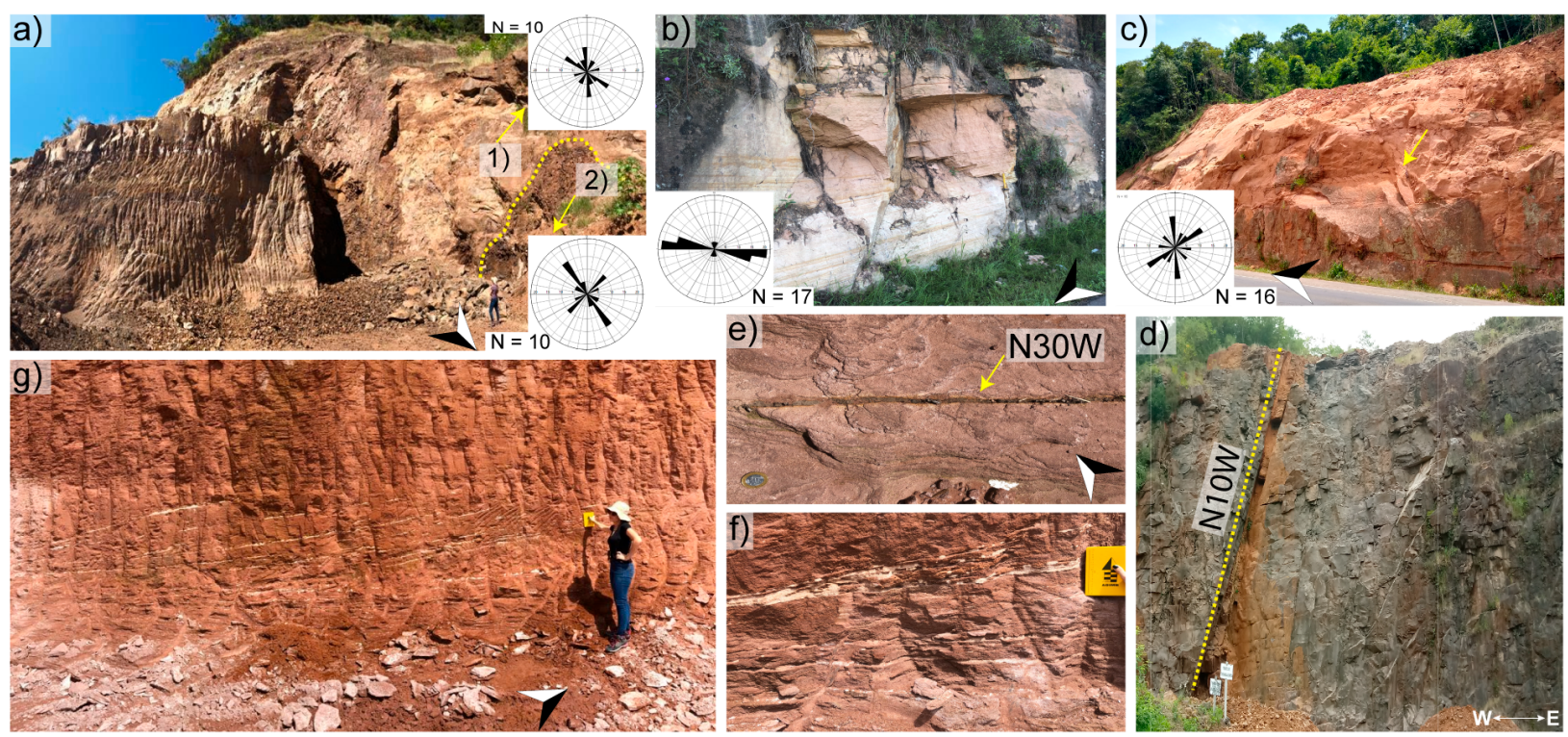

Figure 7. Outcrops of blocks $\mathrm{C}(\mathrm{a}, \mathrm{b}, \mathrm{c}$, and $\mathrm{d}$ ) and $\mathrm{D}$ (e, $\mathrm{f}$ and $\mathrm{g}$ ). (a) Basalt quarry with the dominance of vesicular-amygdaloidal textures. Note the fracture orientations to the NW, NNW, and NE in 1), and NW and NE in 2). (b) Cross-stratification enhanced by levels of prominent iron oxide cement. Note the fracture pattern orientation to the WNW. (c) Fractured sandstone with an evident pattern of fractures to the NE (yellow arrow) and NNW. The sandstones are limited in the left by a basaltic dike oriented to the EW. (d) Basalts with columnar jointing and a fault oriented to the N10W crossing the vertical wall. (e) N30W open fracture filled with smectite. (f and g) Kaolinite cement associated with cross-stratifications. The north is indicated by the black/white arrow.
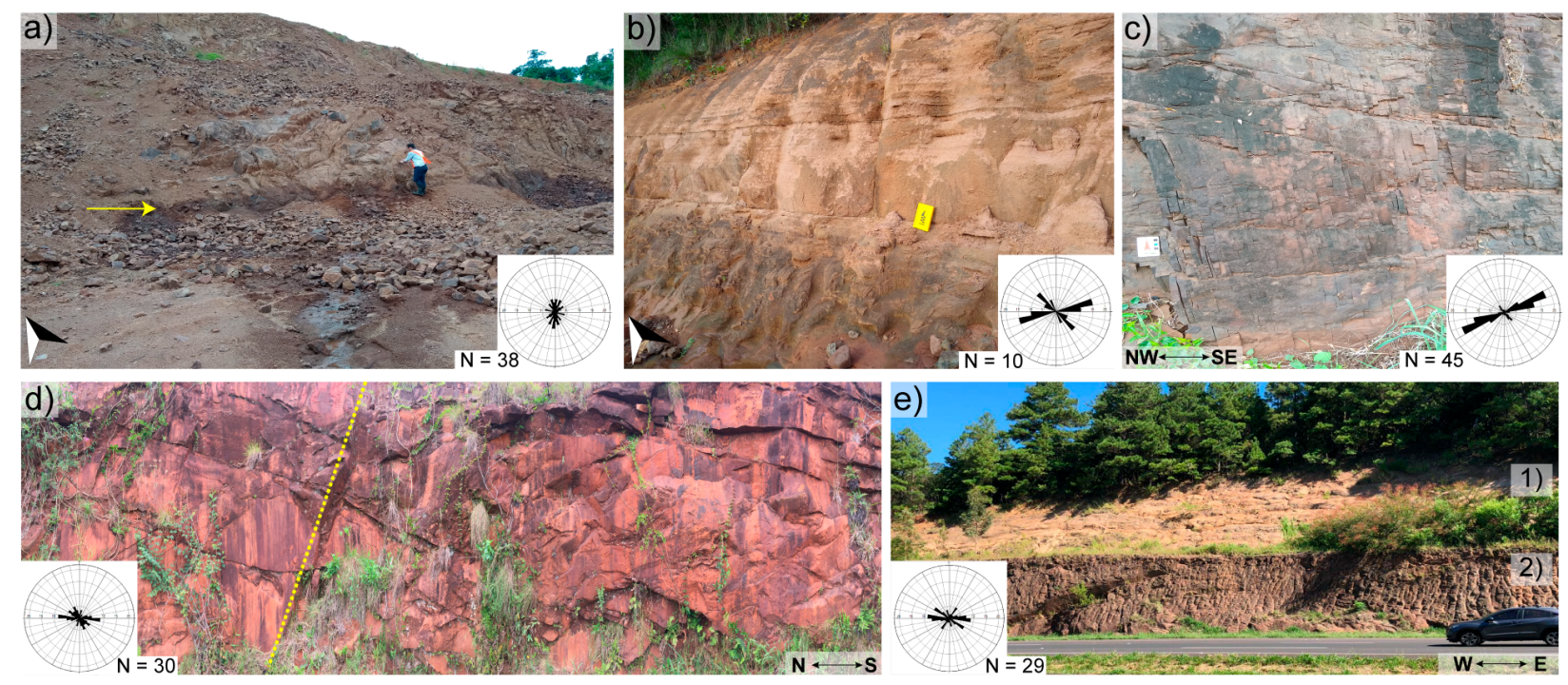

Figure 8. Outcrops of the blocks E (a, b) and F (c, d, e). (a) Basalt quarry showing a well-developed vesicular-amygdaloidal texture, horizontal fractures, and water percolation (yellow arrow). Note the fracture orientations to the NNE. (b) Sandstone near the contact with basalts. Fracture pattern orientations to the NW and ENE. (c) Basalt with prominent weathering features and fractures oriented to the ENE. (d) Dense fractures in sandstone with orientation to the WNW and NW. (e) Vesicular-amygdaloidal basalt (1) with prominent weathering overlying sandstone (2) with fracture pattern oriented to the WNW and, subordinately, the NE. The north is indicated by the black/white arrow.

Precambrian structures and strains associated with the Gondwana breakup between the Jurassic and Cretaceous periods (Milani and Ramos 1998, Milani et al.2007). The structures with such orientations promoted the relative movement of the structural blocks in the study area and the generation of fracture sets as a product of the stress propagated into the rocks through time. The relative movement between blocks is the primary control in the compartmentalization of both the GAS and SGAS in the study area and corroborates previous interpretations made by Araújo et al. (1995, 1999), Machado (2005), Machado and Freitas (2005), and Soares (2008) in other areas of the Paraná Basin. In the study area, the fault systems are associated with the geomorphologic expression of features as the valleys of Sinos, Rolante, Paranhana, Ilha and Areia rivers (Fig. 1). Differences observed in the orientation patterns of fractures in the structural blocks are still under investigation. Three main possibilities include:

- local changes in the stress field caused by fault reactivations;

- different geomechanical behavior caused by diagenesis (e.g., cementation, dissolution);

- non-tectonic origin of some fractures (e.g., lava cooling processes).

The altimetric position of the Botucatu-Serra Geral contact ranges over about $400 \mathrm{~m}$ and is a function of the synsedimentary 

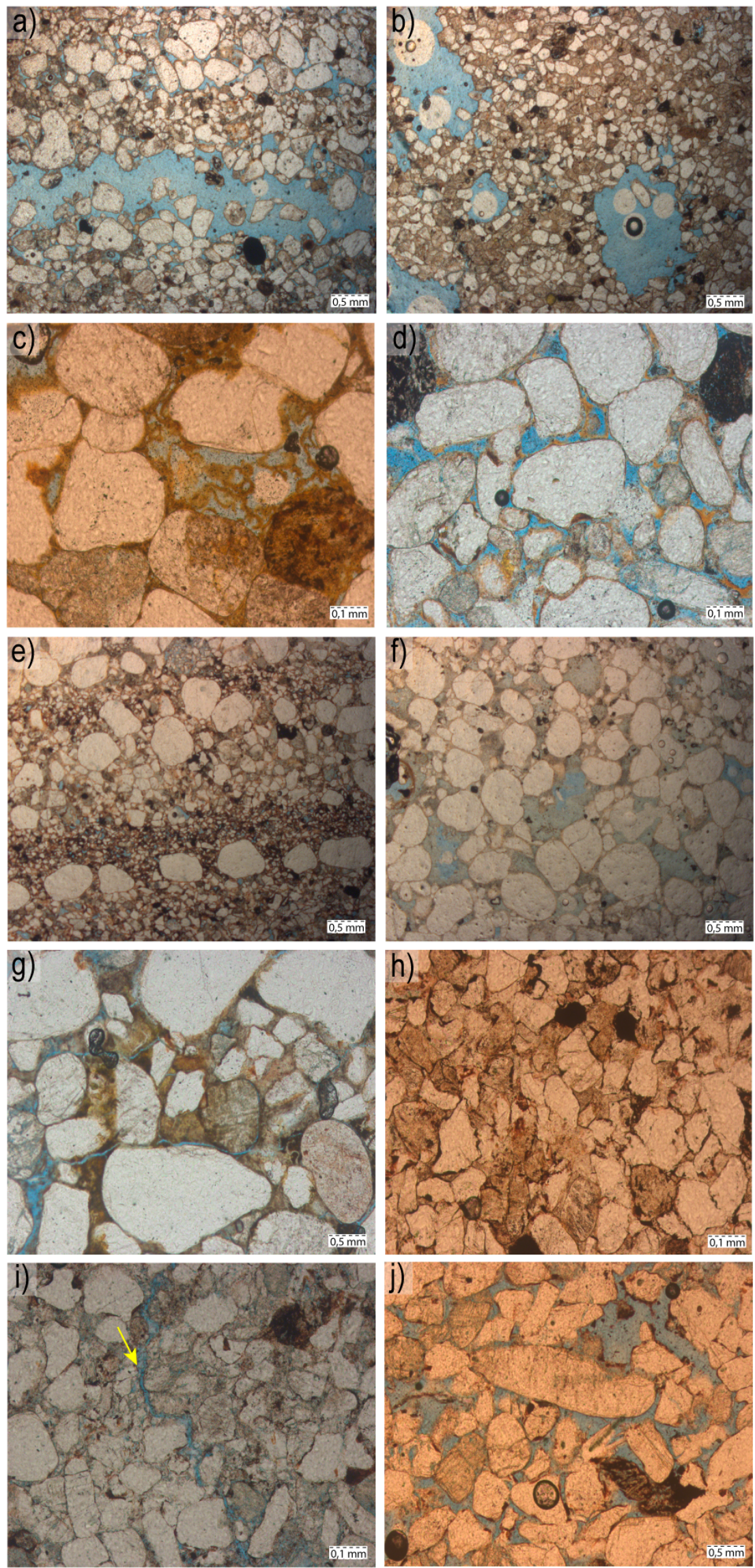

Figure 9. Photomicrography of sandstone thin sections. (A) Moderately sorted and rounded fine-to-medium grained sandstone with intergranular porosity and a very porous continuous conduit associated with an open microfracture. (B) Pores isolated by the presence of cement. (C) Example of unconnected intergranular pores through their obstruction by iron oxide cement. (D) Incipient iron oxide cement in sandstone with $13.3 \%$ of porosity. (E) Low porosity (3\%) in quartzous sandstone. The level with coarse-grained grains represents grain flow intercalated with grain fall in aeolian dune deposits. (F) Kaolinite as cement precipitated into intergranular pores. Note the light blue color of the pores indicating the presence of the cement. (G) Intergranular porosity locally obstructed by iron oxide cement. (H) Arkose with very low porosity. (I) An open fracture (yellow arrow) in sandstones affected by the thermal metamorphism near the Botucatu-Serra Geral contact. (J) Very porous sandstone derived from open intergranular space and fractures. 
Table 5. Porosity and cement content (\%) from sandstone thin sections for each block.

\begin{tabular}{ccccc}
\hline Block & $\begin{array}{c}\text { Thin } \\
\text { section }\end{array}$ & Porosity & $\begin{array}{c}\text { Cement } \\
\text { (Kaolinite) }\end{array}$ & $\begin{array}{c}\text { Cement } \\
\text { (Iron Oxide) }\end{array}$ \\
\hline A & $113-\mathrm{D}$ & 7.3 & 25 & 13 \\
A & 112 & 17.5 & 19 & 6 \\
B & 109 & 8.6 & 38 & 5 \\
C & 19 & 2 & 27 & 10 \\
C & 23 & 13.3 & 13 & 2 \\
D & 116 & 11.8 & 27 & 5 \\
D & 118 & 3 & 31 & 12 \\
D & 119 & 1.3 & 44 & 0 \\
E & $2-B$ & 12.5 & 17 & 3 \\
F & $7-B$ & 1.3 & 9 & 11 \\
F & $7-C$ & 17 & 15 & 2 \\
F & $7-D$ & 14 & 10 & 4 \\
\hline
\end{tabular}

variation in giant decametric dunes of the Botucatu palaeo-desert or a posteriori relative vertical movement of each structural block (Araújo et al. 1995, 1999, Scherer 2002). The analysis of the aquifers in the geological sections $\mathrm{A}-\mathrm{A}(\mathrm{NW}-\mathrm{SE})$ and B-B'(WNW-ESE) (Fig. 10) shows their relationships with the structural blocks $\mathrm{A}$ to $\mathrm{F}$ and the variation in the elevation along the Botucatu-Serra Geral contact. The surface that defines this lithological contact differently dips in each block, as follows: to SW at block A; to W at block B; to S at block C; to SW at block D; to NW at block E; and to SE at block F. These dipping angles, associated with the potentiometric surfaces, helped identify the recharge zones in the Northwest and Center-South areas. Discharge zones occur in the Southeast, where the groundwater flow is parallel with the EW orientation of the Sinos River.

The surface structural data corroborate the pattern of the predominance of EW and NE fractures for sandstones and basalts in all structural blocks. Subsurface data extracted from

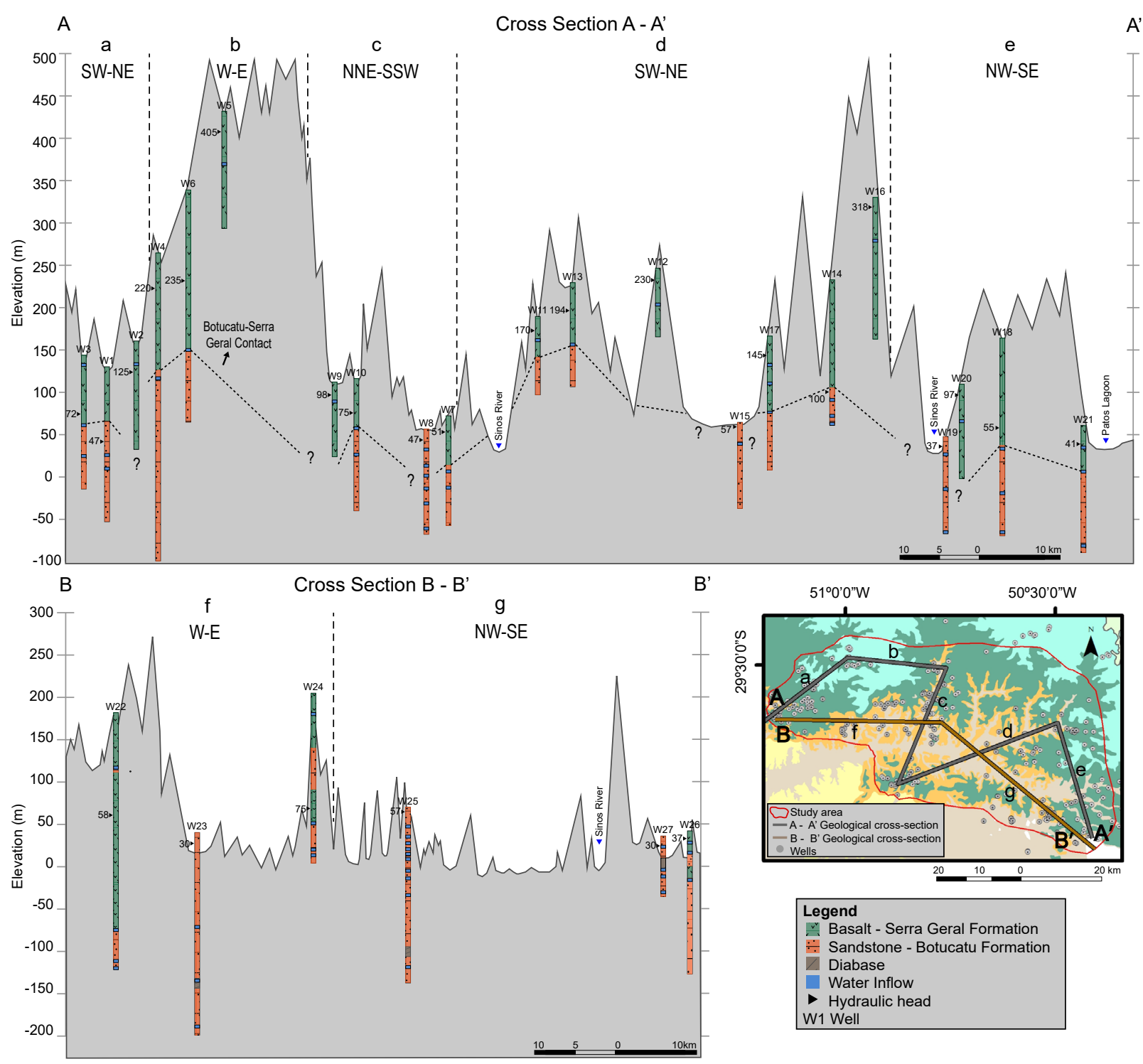

Figure 10. Geological sections along the six structural blocks in the study area. A-A' section shows the altimetric elevation of the BotucatuSerra Geral contact, the water inlet positions, and piezometric levels. Note the intercalation of sandstones and basalts, diabase dikes, water inlets, and piezometric levels. Dashed lines indicate each interval of the A-A' and B-B' sections (see inset map). 
a borehole optical log at Block E (Cantagalo borehole) reinforced the predominance of these orientations. It attests to the validity of surface structural data for geological and hydrogeological purposes, i.e., the stress field near the surface does not significantly alter structural data patterns. Comparing fracture measurements and regional lineaments, patterns are similar on different scales, both in the GAS and SGAS, as evidenced by the geomorphological patterns observed in the Sinos and Rolante rivers. Furthermore, it agrees with structural analyses previously published by Reginato and Strieder (2006), Heine (2008), and Matos et al. (2018) in the Rio Grande do Sul state, and Fernandes et al. (2012, 2016), in the São Paulo state.

The flow rate and specific capacity of wells producing water from the GAS and SGAS indicated more groundwater production in wells that drilled both aquifers. The more productive regions were blocks A and F, in the Northwest and Southeast, respectively. They presented high porosity associated with fractures (SGAS) and a low degree of cementation (GAS), i.e., primary and secondary porosities (Machado 2005). Intercalations observed in wells of the geological section B-B' suggest that the same fracture sets might have propagated both in the sandstones and in the basalts, promoting a potential connection of the aquifers (Fig. 10). However, the connection of the GAS and SGAS needs more studies to corroborate the results of Matos (2020), who identified the upward recharge from the (pre-) GAS to the SGAS near the study area. In block F, the high productivity is a product of the discharge zone and a high density of fracturing that increases porosity in arkose sandstones, from $1.3 \%$ in purely granular to $17 \%$ in open fractures below the sandstone-basalt contact. A sample of block C with a $13.3 \%$ porosity in arkose sandstone with a dense network of fractures corroborated that connection promoted by this type of structure, allowing more effective water percolation into the rock, avoiding cement precipitation, and keeping intergranular and fractures opened. In areas with a low density of fractures, such as block D, sandstones have groundwater that slowly migrates within the pore system due to the restriction of circulation imposed by the types of cement and pore throats.

The integration of all results obtained from a multiscale approach supported the development of a 2-D conceptual hydrogeological model to the study area (Fig. 11). Additional data must be continuously input into the database to improve and test the accuracy of the model. The compartmentalization of aquifers and their subdivision into structural blocks show the geomorphological expression and the range of the altimetric position of the GAS/SGAS contact. Additionally, it demonstrates the orientation of the main tectonic structures that control such contact.

\section{CONCLUSION}

Geological analyses of tectonic, structural, sedimentological, petrographic, and diagenetic aspects of aquifers have contributed to understand productivity data and to integrate all datasets. All six structural blocks identified have their limits defined by fault zones expressed as regional lineaments. This compartmentalization defines the complex behavior of aquifers in terms of productivity. A total of $93 \%$ of the wells drilled in both granular and fractured aquifers showed a water inlet in the sandstone-basalt contact, attesting that this surface develops high storage and flow and, therefore, constitutes a reliable indicator of good productivity. This contact is particularly important because it ranges over $400 \mathrm{~m}$ in elevation as consequence of vertical displacement along with fault systems and paleo-geomorphological surfaces, and any predictive criterium must consider this condition.

The most productive blocks have a relationship with many different controlling parameters such as the contact between aquifers, the recharge $\mathrm{x}$ discharge zones, geomorphology, and the potential connection of the aquifers by fractures. The internal network of fractures in basalts created by

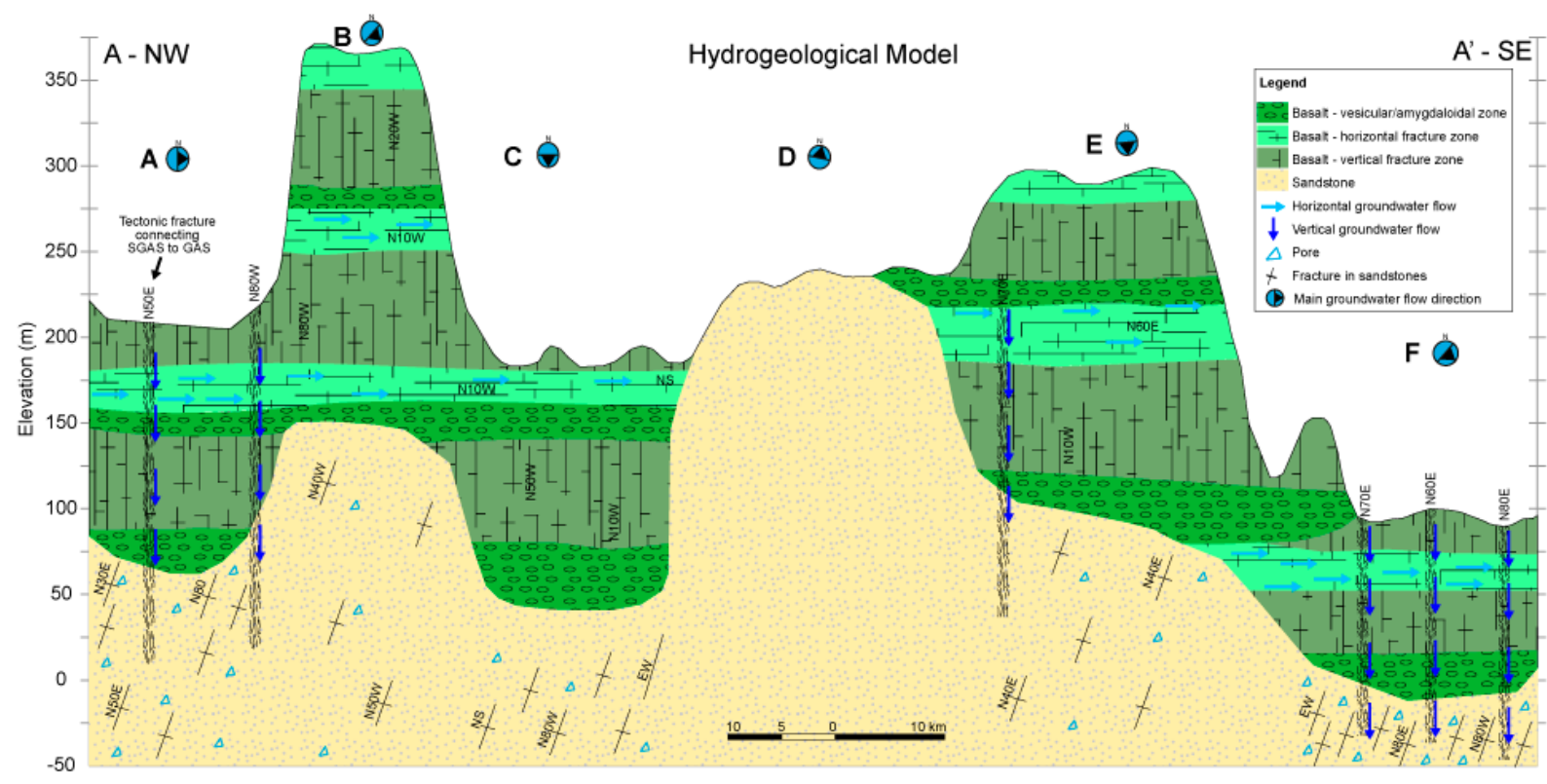

Figure 11. Conceptual hydrogeological model showing the altimetric variation in the GAS-SGAS contact in different blocks, the preferential groundwater flow, and the porosity of sandstones associated with fractures present in both aquifers. 
columnar jointing, the tectonic fractures, the contact of different lava flows, the water stored in vesicular zones, and the intergranular porosity, dependent on both degree of cementation and water percolation into fractures, also influence the productivity of groundwater. The integration of all results and the discussion presented in this study support the proposition of a hydrogeological conceptual model based on many different interdependent factors, which control the productivity in each structural block, detailed through an integrated approach to better understand the complexity of the aquifers and provide reliable predictions of productivity.

\section{ACKNOWLEDGMENTS}

RCS thanks the financial support received as a scholarship from PROSUC/CAPES Program. PPGEO-UNISINOS and IPHUFRGS provided laboratory and fieldwork facilities including software, sample preparation, and vehicles. The technical staff of LASERCA (Gustavo, Graciela, Diego, Milena, Gabriel, and Leonardo) and Thin Section and Sample Preparation Laboratory (Lauro Rosa and Adriano Xavier) were fundamental to achieve excellent results in this research. We especially thank George Olufunmilayo Gasper for helping with the OTV logging acquisition and WellCad data interpretation. Mauricio Righi helped with petrographic analysis and modal counting. The VizGEO research group provided facilities and scientific discussions. We thank the Brazilian Geological Survey (CPRM-SIAGAS), CORSAN, SEHASB, and HidroGeo Perfurações LTDA for providing well-related data. José Luiz Flores Machado, Raquel Binotto, and Joice Cagliari critically read and improved a previous version of the manuscript. Anonymous editor and reviewers provided careful and detailed revisions that improved the quality of the manuscript. FMWT thanks the grant of the National Council for Scientific and Technological Development (CNPq proc. 311204/2017-1)

\section{ARTICLE INFORMATION}

Manuscript ID: 20200056. Received on: 06/25/2020. Approved on: 04/05/2021

R.S.: conceptualization, methodology, field data acquisition, borehole data processing, writing of the manuscript draft, and preparation of figures. F.T.: conceptualization, methodology, supervision, field data acquisition, English review of the manuscript, funding acquisition, and review \& editing. P.R.: conceptualization, methodology, supervision, facilities, field and borehole data acquisition, and review \& editing. P.S.: conceptualization, methodology, borehole data acquisition and processing, and review. L.S.: methodology, field data processing, figure preparation, and review.

Competing interests: The authors declare no competing interests.

\section{REFERENCES}

Almeida F.F.M., Melo M.S. 1981. A Bacia do Paraná e o vulcanismo mesozóico: mapa geológico. Escala 1:500.000. São Paulo: Instituto de Pesquisas Tecnológicas do Estado de São Paulo, Brasil. v. 1.

Araújo L.M., França A.B., Potter P.E. 1995. Aquífero gigante do Mercosul no Brasil, Argentina, Paraguai e Uruguai: mapas hidrogeológicos das formações Botucatu, Pirambóia, Rosário do Sul, Buena Vista, Misiones e Tacuarembó. Curitiba: Universidade Federal de Paraná, Biblioteca de Ciência e Tecnologia, Centro Politécnico.

Araújo L.M., França A.B., Potter P.E. 1999. Hydrogeology of the Mercosul aquifer system in the Paraná and Chaco-Paraná basins, South America, and comparison with the Navajo-Nugget aquifer system, USA. Hydrogeology Journal, 7:317-336. https://doi.org/10.1007/s100400050205

CPRM. 2008. Mapa Geológico do Estado do Rio Grande do Sul. Escala 1:750.000. Porto Alegre, Serviço Geológico do Brasil. Available from: http://www.cprm.gov.br/publique/media/geologia_basica/cartografia regional/mapa_rio_grande_sul.pdf. Accessed on: Nov. 10, 2020.

Dafny E., Burg A., Gvirtzman H. 2006. Deduction of groundwater flow regime in a basaltic aquifer using geochemical and isotopic data: the Golan heights, Israel case study. Journal of Hydrology, 330(3-4):506-524. https:// doi.org/10.1016/j.jhydrol.2006.04.002

Deutsch W.J., Everett A.J., Krupka K.M. 1982. Solubility equilibria in basalt aquifers: The Columbia Plateau, eastern Washington, U.S.A. Chemical Geology, 36(1-2):15-34. https://doi.org/10.1016/0009-2541(82)90037-7

Domenico P.A., Schwartz F.W. 1990. Physical and chemical hydrogeology. New York:John Wiley \& Sons, 824 p.https://doi.org/10.1017/S0016756800019890

Erlank A.J., Marsh J.S., Duncan A.R., Miller R.M.G., Hawkesworth, C.J., Betton, P.J., Rex D.C. 1984. Geochemistry and petrogenesis of the Etendeka volcanic rocks from SW Namibia. Geological Society of South Africa Special Publication, 13:195-245.

Fernandes A.J., Maldaner C.H., Negri F., Rouleau A., Wahnfried I. 2016 Aspects of a conceptual groundwater flow model of the Serra Geral basalt aquifer (São Paulo, Brazil) from physical and structural geology data. Hydrogeology Journal, 24:1199-1212. https://doi.org/10.1007/ s10040-016-1370-6
Fernandes A.J., Negri F.A., Azevedo Sobrinho J.M., Varnier C. 2012 Análise de fraturas dos basaltos do Aquífero Serra Geral e o potencial de recarga regional do Sistema Aquífero Guarani. Boletín Geológico y Minero, 123(3):325-339.

Folk R.L. 1974. Petrology of Sedimentary Rocks. Austin: Hemphill Publishing Co., 182 p.

França A.B., Araújo L.M., Maynard J.B., Potter P.E. 2003. Secondary porosity formed by deep meteoric leaching: Botucatu eolianite, southern South America. AAPG Bulletin, 87(7):1073-1082. https://doi.org/10.1306/02260301071

Freitas M.A. 2016. Hidrogeoquímica e Isotopia de Águas com Alta Salinidade do Sistema Aquífero Serra Geral na Região do Alto Rio Uruguai, Brasil. $\mathrm{PhD}$ Thesis, Universidade Federal do Rio Grande do Sul, Porto Alegre, 195 p.

Fulfaro V.J., Saad A.R., Santos M.V., Vianna R.B. 1982. Compartimentação e evolução tectônica da Bacia do Paraná. Revista Brasileira de Geociências, 12(4):590-611

Gastmans D., Chang H.K., Hutcheon I. 2010. Groundwater geochemical evolution in the northern portion of the Guarani Aquifer System (Brazil) and its relationship to diagenetic features. Applied Geochemistry, 25(1):1633. https://doi.org/10.1016/j.apgeochem.2009.09.024

Gastmans D., Hutcheon I., Menegário A.A., Chang H.K. 2016. Geochemical evolution of groundwater in a basaltic aquifer based on chemical and stable isotopic data: Case study from the northeastern portion of Serra Geral Aquifer, São Paulo state (Brazil). Journal of Hydrology, 535:598-611. https://doi.org/10.1016/j.jhydrol.2016.02.016

Gastmans D., Chang H.K. 2012. Circulação das águas subterrâneas do Sistema Aquífero Guarani nas proximidades da zona de afloramentos no Estado de São Paulo. In: XVII Congresso Brasileiro de Águas Subterrâneas, 17., 2012, Bonito. Annals...v. 1.p. 1-4. Available from: https:// aguassubterraneas.abas.org/asubterraneas/article/view/27644/17901. Accessed on: Nov. 10, 2020.

Gastmans D., Mira A., Kirchheim R., Vives L., Rodríguez L., Veroslavsky G. 2017. Hypothesis of groundwater flow through geological structures in Guarani Aquifer System (GAS) using chemical and isotopic data. Procedia Earth and Planetay Science, 17:136-139. https://doi.org/10.1016/j.proeps.2016.12.030 
Heine C.A. 2008. Análise de sustentabilidade de uso do sistema aquifero Guarani em Ivoti/RS. PhD Thesis, Universidade do Vale do Rio dos Sinos, São Leopoldo, 375 p.

Jalludin M., Razack M. 1994. Analysis of pumping tests, with regard to tectonics, hydrothermal effects and weathering, for fractured Dalha and stratiform basalts, Republic of Djibouti. Journal of Hydrology, 155(1-2):237250. https://doi.org/10.1016/0022-1694(94)90167-8

Jerram D.A., Widdowson M. 2005. The anatomy of continental flood basalt provinces: geological constraints on the processes and products of flood volcanism. Lithos, 79(3-4):385-405. https://doi.org/10.1016/j. lithos.2004.09.009

Jerram D.A., Mountney N., Holzfoster F., Stollhofen H. 1999. Internal stratigraphic relationships in the Etendeka Group in the Huab Basin, NW Namibia: understanding the onset of food volcanism. Journal of Geodynamics, 28(4-5):393-418. https://doi.org/10.1016/S0264-3707(99)00018-6

Jerram D.A., Mountney N., Howell J.A., Long D., Stollhofen H. 2000. Death of a sand sea: an active aeolian erg systematically buried by the Etendeka flood basalts of NW Namibia. Journal of the Geological Society, 157(3):513516. https://doi.org/10.1144/jgs.157.3.513

Johnson G.S., Frederick D.B., Cosgrove D.M. 2002. Evaluation of a pumping test of the Snake River Plain aquifer using axial-flow numerical modeling. Hydrogeology Journal, 10(3):428-437. https://doi.org/10.1007/ s10040-002-0201-0

Katpatal A.M.P., Pophare A.M., Lamsoge B.R. 2014. A groundwater flow model for overexploited basaltic aquifer and Bazada formation in India. Environmental Earth Science, 72:4413-4425. https://doi.org/10.1007/ s12665-014-3342-2

Kulkarni H., Lalwani A., Deolankar S.B. 1997. Selection of appropriate pumping systems for bore wells in the Deccan basalt of India. Hydrogeology Journal, 5(3):75-81. https://doi.org/10.1007/s100400050258

Kulkarni H.S.B., Deolankar A., Lawwani B., Joseph S., Pawar S. 2000. Hydrogeological framework of the Deccan basalt groundwater systems, West-central India. Hydrogeology Journal, 8:368-378. https://doi. org/10.1007/s100400000079

Lindholm G.F., Vaccaro J.J. 1988. Region 2, Columbia Lava Plateau. The Geology of North America. Hydrogeology, 10(2):37-50. https://doi. org/10.1130/DNAG-GNA-O2.37

Machado J.L.F. 2005. Compartimentação espacial e arcabouço hidroestratigráfico do Sistema Aqüifero Guarani no Rio Grande do Sul. $\mathrm{PhD}$ Thesis, Universidade do Vale do Rio dos Sinos, São Leopoldo, 237 p.

Machado J.L.F., Freitas M.D. 2005. Projeto Mapa Hidrogeológico do Rio Grande do Sul: Relatório Final. Escala 1:750.000. Porto Alegre: Companhia de Pesquisa de Recursos Minerais (CPRM).

Matos A.B. 2020. Compartimentação Estrutural e Interações Hidrogeológicas entre o Sistema Aquífero Guarani e Serra Geral na Região Nordeste do Estado do Rio Grande do Sul. PhD Thesis, Universidade Federal do Rio Grande do Sul, Porto Alegre, $195 \mathrm{p}$.

Matos A.B., Reginato P.A.R., Athayde G.B. 2018. Compartimentação hidrogeológica do Sistema Aquífero Guarani na escarpa da Serra Geral no nordeste do Rio Grande do Sul. Águas Subterrâneas, 32(1):130-139. https://doi.org/10.14295/ras.v32i1.28965

Milani E.J. 1997. Evolução tectono-estratigráfica da Bacia do Paraná e seu relacionamento com a geodinâmica fanerozóica do Gonduana SulOcidental. PhD Thesis, Universidade Federal do Rio Grande do Sul, Porto Alegre, $255 \mathrm{p}$.

Milani E.J., Melo J.H.G., Souza P.A., Fernandes L.A., França A.B. 2007. Bacia do Paraná. Boletim de Geociências da Petrobras, 15(2):265-287.

Milani E.J., Ramos V.A. 1998. Orogenias paleozóicas no domínio sul-ocidental do Gondwana e os ciclos de subsidência da Bacia do Paraná. Revista Brasileira de Geociências, 28(4):473-484. http://dx.doi. org/10.25249/0375-7536.1998473484

Mountney N., Howell J., Flint S., Jerram D.A. 1999. Relating eolian bounding-surface geometries to the bed forms that generated them: Etjo Formation, Cretaceous, Namibia. Geology, 27(2):159-162. https://doi. org/10.1130/0091-7613(1999)027<0159:REBSGT>2.3.CO;2
Naik P.K., Awasthi A.K., Anand A.V.S.S., Mohan P.C. 2001. Hydrogeologic framework of the Deccan terrain of the Koyna River basin, India. Hydrogeology Journal, 9:243-264. https://doi.org/10.1007/s100400100123

Peate D.W., Hawkesworth C.J., Mantovani M.S., Shukowsky W. 1990. Mantle plumes and flood basalt stratigraphy in the Paraná Basin, South America. Geology, 18(12):1223-1226. https://doi. org/10.1130/0091-7613(1990)018<1223:MPAFBS>2.3.CO;2

Petry K., Almeida D.P.M., Zerfass H. 2005. O vulcanismo Serra Geral em Torres, Rio Grande do Sul, Brasil: empilhamento estratigráfico local e feições de interação vulcano-sedimentar. Gaea, 1(1):36-47.

Rebouças A.C., Fraga C.G. 1988. Hidrogeologia das rochas vulcânicas do Brasil. Águas Subterrâneas, 12(1):30-55. https://doi.org/10.14295/ras.v12i1.11282

Reginato P.A.R., Ahlert S., Schneider V.E. 2013. Caracterização hidroquímica do sistema aquífero Serra Geral na região nordeste do Rio Grande do Sul. Águas Subterrâneas, 27(1):65-78. https://doi.org/10.14295/ras.v27i1.27061

Reginato P.A.R., Strieder A.J. 2006. Caracterização estrutural dos aquíferos fraturados da Formação Serra Geral na região nordeste do estado do Rio Grande do Sul. Revista Brasileira de Geociências, 36(1):13-22.

Reis G.S., Mizusaki A.M.P., Roisenberg A., Rubert R.R. 2014. Formação Serra Geral (Cretáceo da Bacia do Paraná): um análogo para os reservatórios ígneo-básicos da margem continental brasileira. Pesquisas em Geociências, 41(2):155-168. https://doi.org/10.22456/1807-9806.78093

Renne P.R., Deckart K., Ernesto M., Féraud G., Piccirillo E.M. 1996. Age of the Ponta Grossa dike swarm (Brazil), and implications to Paraná flood volcanism. Earth and Planetary Science Letters, 144(1-2):199-211. https:// doi.org/10.1016/0012-821X(96)00155-0

Scherer C.M.S. 2000. Eolian dunes of the Botucatu Formation (Cretaceous) in southernmost Brazil: morphology and origin. Sedimentary Geology, 137(1-2):63-84. https://doi.org/10.1016/S0037-0738(00)00135-4

Scherer C.M.S. 2002. Preservation of aeolian genetic units by lava flows in the Lower Cretaceous of the Paraná Basin, southern Brazil. Sedimentology, 49(1):97-116. https://doi.org/10.1046/j.1365-3091.2002.00434.x

Schneider R.L., Mühlmann H., Tommasi R.A., Medeiros R.A., Daemon R.F., Nogueira A.A. 1974. Revisão Estratigráfica da Bacia do Paraná. In: Congresso Brasileiro de Geologia Porto Alegre, 28., 1974. Annals... v. 1. p. 41-65.

Soares A.P. 2008. Variabilidade espacial no Sistema Aquifero Guarani: controles estratigráficos e estruturais. PhD Thesis, Universidade Federal do Rio Grande do Sul, Porto Alegre, $196 \mathrm{p}$

Tomasi L.C., Roisenberg A. 2019. Influência da Tectônica-Rúptil na Hidrogeoquímica do Sistema Aquífero Serra Geral na Bacia Hidrográfica do Rio Ijuí, RS. Revista Águas Subterrâneas, 33(3):292-302. https://doi. org/10.14295/ras.v33i3.29262

Turner S.P., Regelous M., Kelley S., Hawkesworth C., Mantovani M.S.M. 1994. Magmatism and continental break-up in the South Atlantic: high precision ${ }^{40} \mathrm{Ar}-{ }^{39} \mathrm{Ar}$ geochronology. Earth and Planetary Science Letters, 121(3-4):333-348. https://doi.org/10.1016/0012-821X(94)90076-0

Uhl Jr. V.W.J.R., Joshi V.G. 1986. Results of pumping tests in the Deccan Trap Basalts of Central India. Journal of Hydrology, 86(1-2):147-168. https://doi. org/10.1016/0022-1694(86)90011-9

Wahnfried I.D. 2010. Modelo conceitual de fluxo do Aquitarde Serra Geral e do Sistema Aquifero Guarani na região de Ribeirao Preto, SP. PhD Thesis, Universidade de São Paulo, São Paulo, 135 p.

Waichel B.L., Lima E.F., Viana A.R., Scherer C.M., Bueno G.V., Dutra G. 2012. Stratigraphy and volcanic facies architecture of the Torres Syncline, Southern Brazil, and its role in understanding the Paraná-Etendeka Continental Flood Basalt Province. Journal of Volcanology and Geothermal Research, 215-216:7482. https://doi.org/10.1016/j.jvolgeores.2011.12.004

Whiteman K.J., Vaccaro J.J., Gonthier J.B., Bauer H.H. 1994. The hydrogeologic framework and geochemistry of the Columbia Plateau aquifer system, Washington, Oregon and Idaho. USGS Professional Paper, B1-B73. https://doi.org/10.3133/pp1413B

White I.C. 1908. Relatório final da Comissão de Estudos das Minas de Carvão de Pedra do Brasil. Departamento Nacional de Produção Mineral. 